\title{
The Influence of the Ligand in the Iridium Mediated Electrocatalyic Water Oxidation
}

\author{
Bas van Dijk, Gabriel Menendez Rodriguez, Longfei Wu, Jan P. Hofmann, Alceo Macchioni,* \\ and Dennis G. H. Hetterscheid*
}

Cite This: ACS Catal. 2020, 10, 4398-4410

Read Online

\section{ACCESS \\ Џlll Metrics \& More \\ Article Recommendations \\ Supporting Information}

ABSTRACT: Electrochemical water oxidation is the bottleneck of electrolyzers as even the best catalysts, iridium and ruthenium oxides, have to operate at significant overpotentials. Previously, the position of a hydroxyl on a series of hydroxylpicolinate ligands was found to significantly influence the activity of molecular iridium catalysts in sacrificial oxidant driven water oxidation. In this study, these catalysts were tested under electrochemical conditions and benchmarked to several other known molecular iridium catalysts under the exact same conditions. This allowed us to compare these catalysts directly and observe whether structure-activity relationships would prevail under electrochemical conditions. Using both electrochemical quartz crystal microbalance experiments and X-ray

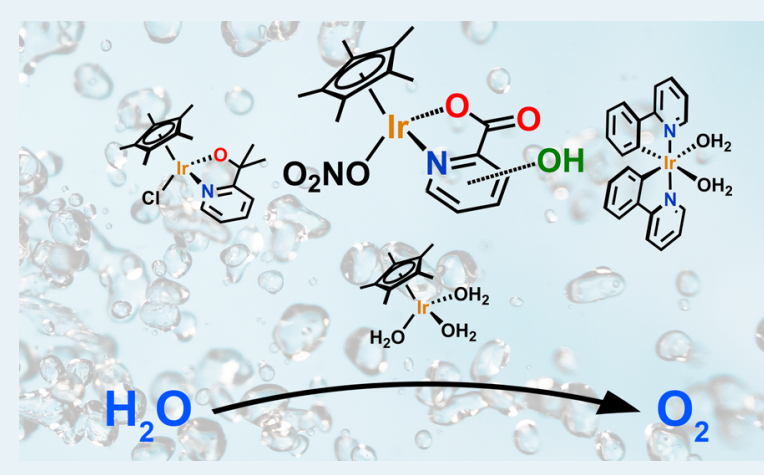
photoelectron spectroscopy, we found that all studied iridium complexes form an iridium deposit on the electrode with binding energies ranging from 62.4 to $62.7 \mathrm{eV}$ for the major $\mathrm{Ir} 4 \mathrm{f}_{7 / 2}$ species. These do not match the binding energies found for the parent complexes, which have a broader binding energy range from 61.7 to $62.7 \mathrm{eV}$ and show a clear relationship to the electronegativity induced by the ligands. Moreover, all catalysts performed the electrochemical water oxidation in the same order of magnitude as the maximum currents ranged from 0.2 to $0.6 \mathrm{~mA} \mathrm{~cm}^{-2}$ once more without clear structure-activity relationships. In addition, by employing ${ }^{1} \mathrm{H}$ NMR spectroscopy we found evidence for $\mathrm{Cp}^{*}$ breakdown products such as acetate. Electrodeposited iridium oxide from ligand free $\left[\operatorname{Ir}(\mathrm{OH})_{6}\right]^{2-}$ or a colloidal iridium oxide nanoparticles solution produces currents almost 2 orders of magnitude higher with a maximum current of $11 \mathrm{~mA} \mathrm{~cm}{ }^{-2}$. Also, this deposited material contains, apart from an $\mathrm{Ir}_{7 / 2}$ species at $62.4 \mathrm{eV}$, an $\mathrm{Ir}$ species at $63.6 \mathrm{eV}$, which is not observed for any deposit formed by the molecular complexes. Thus, the electrodeposited material of the complexes cannot be directly linked to bulk iridium oxide. Small $\mathrm{IrO}_{\mathrm{x}}$ clusters containing few $\mathrm{Ir}$ atoms with partially incorporated ligand residues are the most likely option for the catalytically active electrodeposit. Our results emphasize that structure-activity relationships obtained with sacrificial oxidants do not necessarily translate to electrochemical conditions. Furthermore, other factors, such as electrodeposition and catalyst degradation, play a major role in the electrochemically driven water oxidation and should thus be considered when optimizing molecular catalysts.

KEYWORDS: water oxidation, iridium complexes, electrocatalysis, benchmarking, electrochemical deposition

\section{INTRODUCTION}

Electrolysis of water has been put forward as an interesting method for the storage of renewable energy, thereby countering intermittency problems of, for instance, sunlight and wind energy. Polymer electrolyte membrane (PEM) electrolyzers can achieve high $\mathrm{H}_{2}$ production via proton reduction in water. Nevertheless, the efficiency of electrolysis should still massively be improved, considering that substantial overpotentials and very high loadings of precious metals are required. Specifically, the electrochemical water oxidation reaction is the main bottleneck of electrolyzers. A strategy to potentially improve the water oxidation reaction is the use of molecular iridium and ruthenium (pre-) catalysts. ${ }^{1-11}$ First of all, the ligand system around the active metal center can be altered to enhance activity and lower the overpotential. For example, the water oxidation overpotential of ruthenium based molecular catalysts has improved significantly over the years by various ligand alterations. ${ }^{11}$ In detail, the use of an anionic carboxylate-containing backbone was found to be the key to substantially lower the overpotential and increase the turnover frequency. ${ }^{12}$ Second, by using highly active molecular

Received: January 31, 2020

Revised: March 13, 2020

Published: March 17, 2020 
Chart 1. Structure and Nomenclature of Iridium (Hydroxy)picolinate (1) and other Benchmark (2-5) Complexes Herein Studied

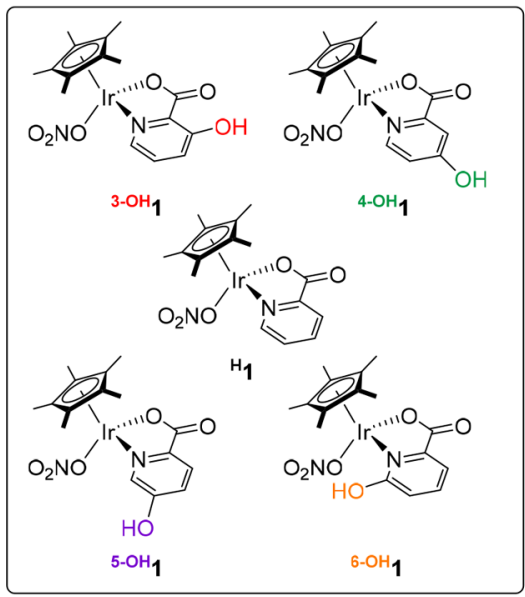

Macchioni

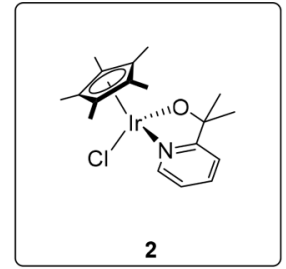

Crabtree

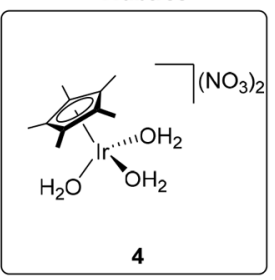

Crabtree/Macchioni

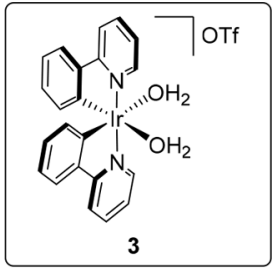

Bernhard

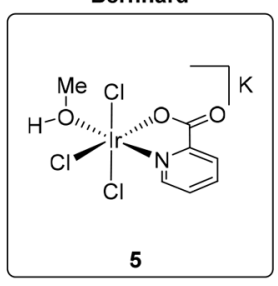

Tejel/Hetterscheid complexes, significantly lower catalyst loadings can be achieved. Conventional heterogeneous catalysts that consist of nanoparticles have inaccessible metal atoms that are not directly involved in catalysis. Ideally, all these metal sites would be exposed to the electrolyte solution where catalysis occurs, for example by incorporating iridium in an inert support. ${ }^{13}$ In this context, the active molecular iridium catalyst [ $\operatorname{Ir}$ (pyalc)$\left.\left(\mathrm{H}_{2} \mathrm{O}\right)_{2}(\mu-\mathrm{O})\right]_{2}{ }^{2+}\left(\right.$ pyalc $=2$ - $\left(2^{\prime}\right.$-pyridyl $)$-2-propanolate $)$ has been heterogenized on a metal oxide support previously by the groups of Sheehan et. al. ${ }^{14}$ That way, $90 \%$ of the iridium in the formed monolayer on the surface was involved in water oxidation, producing $0.5 \mathrm{~mA} \mathrm{~cm} \mathrm{~cm}^{-2}$ current densities at an overpotential $<160 \mathrm{mV}$. Given that organic ligands are still coordinated to the iridium site, it is likely that modifications of the pyalc ligand could further optimize the catalytic performance.

Since the first report of a molecular iridium water oxidation catalyst by Bernhard and co-workers, ${ }^{15}$ many other iridium complexes with structural adjustments have been investigated to improve the water oxidation activity. ${ }^{16-30}$ Nevertheless, general structure-activity relationships for optimizing these catalysts have not been established yet for several reasons. First of all, most of the water oxidation performance of molecular iridium catalysts was explored with sacrificial oxidants such as ceric ammonium nitrate (CAN) or $\mathrm{NaIO}_{4}$ (periodate), and the structure/activity relationship was found to be strongly affected by the nature of the sacrificial oxidant. ${ }^{31,32}$ Only a few studies focused on the electrochemical performance of complexes, which is closer to electrolysis operating conditions. In addition, the activity of molecular iridium complexes has been studied in a broad range of experimental conditions such as $\mathrm{pH}$, buffer, or electrolyte. Moreover, the stability and homogeneous nature of molecular iridium catalysts has been under debate. As it happens, a number of studies report the observation of ligand breakdown products or even the presence of iridium oxide $\left(\mathrm{IrO}_{x}\right)$ nanoparticles during or after catalysis. ${ }^{29,30,33-56}$ Especially the degradation of the anionic pentamethyl cyclopentadienyl $\left(\mathrm{Cp}^{*}\right)$ ligand has been widely observed, and its breakdown mechanism has been extensively investigated. $^{29,30,33-47,57}$ These degradation routes take place both with sacrificial reagents as well as under electrochemical conditions. Under the latter conditions, electrodeposits may be formed when the parent complexes are subjected to oxidative potentials. ${ }^{50,56,58}$ Whether an actual deposit is formed is highly dependent on the experimental conditions. For establishing structure-activity relationships, it is desirable to study complexes with the exact same electrochemical conditions and to investigate any possible degradation pathways.

Recently, we showed that the presence and position of a hydroxyl substituent on deprotonated \#-hydroxypicolinic acid ligands of a series of $\left[\mathrm{Cp}^{*} \mathrm{Ir}^{\mathrm{III}}(\mathrm{L})\left(\mathrm{NO}_{3}\right)\right]$ complexes $\left({ }^{\mathrm{H}} \mathbf{1}\right.$ and ${ }^{\#-O H} \mathbf{1}$ in Chart 1 where $\mathrm{L}$ is the picolinate ligand) had a major influence on their respective sacrificial oxidant driven water oxidation activity. ${ }^{18,22,28} \mathrm{pH}$ was an important variable as the complexes had negligible activity at $\mathrm{pH} 1$ but high activity at $\mathrm{pH}$ 7. The highest turnover number and frequency were obtained with ${ }^{\mathrm{H}} 1$ using $\mathrm{NaIO}_{4}$ as an oxidant. The trend in activity could be explained by the trend in electron-donating character of the ligands of the complexes. In addition, evidence for $\mathrm{Cp}^{*}$ degradation was found based on NMR studies. Nevertheless, these NMR studies also indicated that the hydroxypicolinate ligands most likely remained intact and coordinated to the iridium center. In a later study, the activity of these picolinate complexes was benchmarked to several other known iridium complexes (including 2-5, $\left[\operatorname{Ir}(\mathrm{OH})_{6}\right]^{2-}$ and $\mathrm{IrO}_{x} \cdot n \mathrm{H}_{2} \mathrm{O}$ nanoparticles, having a mean diameter of 2 $\mathrm{nm}$ ) under the exact same conditions, and the nature of the generated active species was discussed. ${ }^{27}\left[\operatorname{Ir}(\mathrm{OH})_{6}\right]^{2-}$ was found to be significantly more active than all other catalysts, at $\mathrm{pH} 7$ with periodate as oxidant. On the basis of that and other results, it was concluded that the active species has to be molecular, containing a few iridium atoms, though its exact nature was not completely disclosed, in particular as far as the possibility that it contains a residual $\mathrm{Cp}^{*}$-fragment and/or other ligands derived from the precursors.

In this study, we explored complexes 1-5 (Chart 1) electrochemically to see whether structurally induced electronic differences of the ligand would translate into different electrochemical water oxidation activity as well. Furthermore, spectroscopic NMR and XPS studies were used to study the active species in more detail. In contrast to the studies with sacrificial oxidants, we found that previously determined structure-activity relationships do not prevail under electro- 

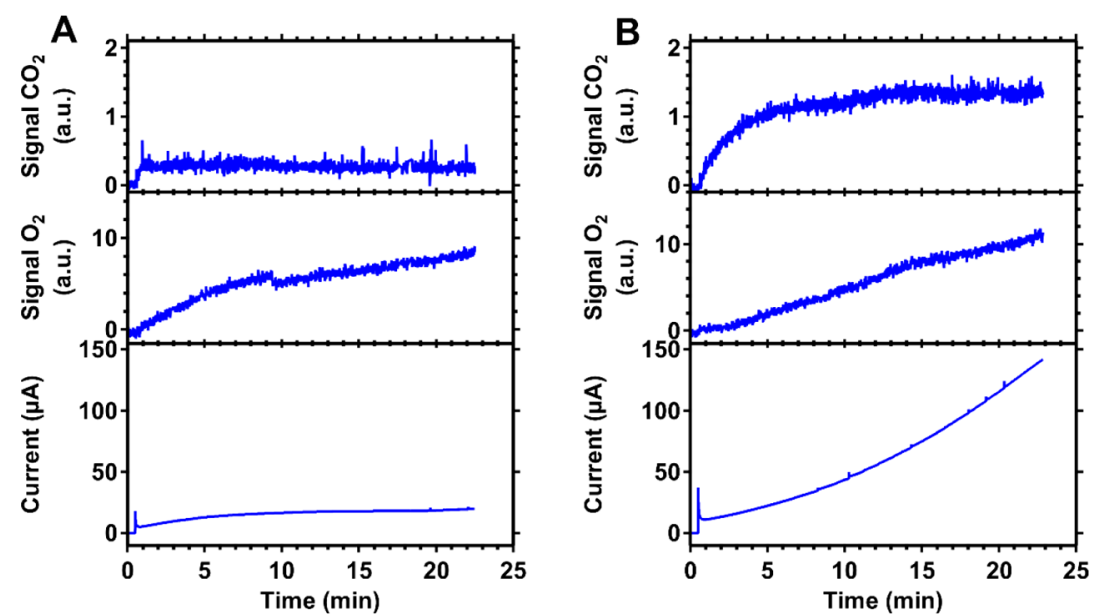

Figure 1. Online electrochemical mass spectrometry measurements of ${ }^{6-\mathrm{OH}} \mathbf{1}(\mathrm{A})$ and ${ }^{\mathrm{H}} \mathbf{1}(\mathrm{B})$ in $0.1 \mathrm{M} \mathrm{HClO}_{4}$ (pH 1 ) with an ionic strength of 0.5 $\mathrm{M}$ by adding $\mathrm{NaClO}_{4}$. Chronoamperometry was performed by initially applying $0.8 \mathrm{~V}$ versus RHE and subsequently $1.8 \mathrm{~V}$. The resulting amperogram is plotted in the bottom panel. Simultaneously recorded mass traces of $m / z 32\left(\mathrm{O}_{2}\right)$ and $m / z 44\left(\mathrm{CO}_{2}\right)$ are depicted in the top panels. A large surface area Au working electrode $\left(0.14 \mathrm{~cm}^{2}\right)$ was used.
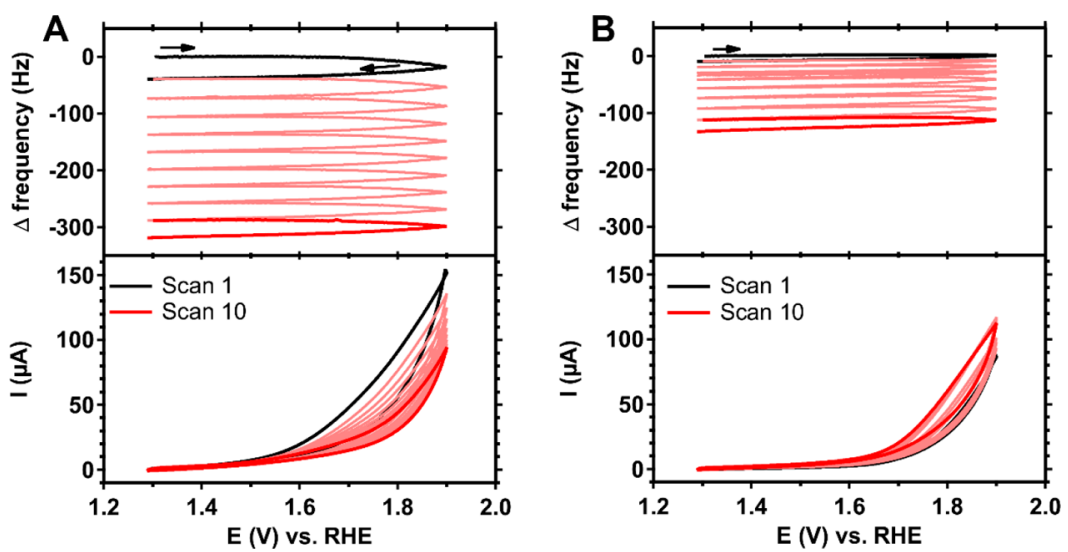

Figure 2. Electrochemical quartz crystal microbalance measurements of ${ }^{6-\mathrm{OH}_{1}}$ (A) and ${ }^{\mathrm{H}} \mathbf{1}$ (B) in $0.1 \mathrm{M}$ phosphate buffer at $\mathrm{pH} 7$. The work electrode is a $\mathrm{Au}$ working electrode $\left(0.35 \mathrm{~cm}^{2}\right)$ that was oxidized by performing $10 \mathrm{CV}$ scans in a 1.3 to $2.0 \mathrm{~V}$ potential window in a catalyst-free electrolyte prior to the measurement. The CVs, taken at a scan rate of $0.1 \mathrm{~V} / \mathrm{s}$, are displayed in the bottom panels. Simultaneously, the relative frequency of the oscillating quartz crystal of the work electrode was monitored during the potential cycling in the presence of the catalyst (top panels).

chemical conditions. In fact, only marginal differences in activity between the complexes were found.

\section{RESULTS AND DISCUSSION}

Electrocatalytic $\mathrm{O}_{2}$ Evolution. Cyclic voltammetry $(\mathrm{CV})$ is the first tool used for studying the electrochemical response of a homogeneous catalyst wherein the potential of the work electrode is cycled and plotted versus the current response. For this purpose, a glassy carbon (GC) working electrode and 1 $\mathrm{mM}$ solutions of catalyst in a $0.1 \mathrm{M}$ phosphate buffer of $\mathrm{pH} 7$ with $0.5 \mathrm{M}$ ionic strength by adding $\mathrm{NaClO}_{4}$ were used. The more electron rich complexes ${ }^{4-\mathrm{OH}_{1}}$ and ${ }^{6-\mathrm{OH}_{1}} \mathbf{1}$ produce an oxidizing current starting at $1.55 \mathrm{~V}$ versus the reversible hydrogen electrode (RHE) when the potential is initially increased from 0.8 to $2.1 \mathrm{~V}$ (Figure S1). ${ }^{\mathrm{H}} \mathbf{1},{ }^{3-\mathrm{OH}} \mathbf{1}$, and ${ }^{5-\mathrm{OH}} \mathbf{1}$ start to produce an oxidizing current from a $100 \mathrm{mV}$ higher potential $(1.65 \mathrm{~V})$ onward. Interestingly, no redox waves are observed for the $\mathrm{Ir}^{\mathrm{III}} / \mathrm{Ir}^{\mathrm{IV}}$ redox couple, which is in line with other iridium complexes studied electrochemically at this $\mathrm{pH} .{ }^{16,45,49,50,55,59}$ Instead, the observed irreversible oxidative wave is most likely catalytic in nature. To prove that water is oxidized to $\mathrm{O}_{2}$, online electrochemical mass spectrometry (OLEMS) was employed. ${ }^{60}$ This technique provides means to measure the types of gases that are evolved at the electrode by the use of a porous Teflon tip closely approaching the surface of the electrode. This way, the mass traces of gases can be detected as a function of applied potential. Specifically, $\mathrm{O}_{2}$ and $\mathrm{CO}_{2}$ with $\mathrm{m} / z$ traces of 32 and 44 , respectively, were of interest. ${ }^{6-\mathrm{OH}} \mathbf{1}$ and ${ }^{\mathrm{H}} \mathbf{1}$ were tested with OLEMS by performing chronoamperometry $(\mathrm{CA})$ at a static potential of $1.8 \mathrm{~V}$ (Figure 1). All catalysts produce significant currents at this potential (Figure $\mathrm{S} 1$ ). ${ }^{6-\mathrm{OH}} \mathbf{1}$ and ${ }^{\mathrm{H}} \mathbf{1}$ start to produce oxygen immediately once the potential is switched to $1.8 \mathrm{~V}$. For both complexes, the produced current at $1.8 \mathrm{~V}$ is not static and increases over time (Figure $1 \mathrm{~A}$ and $\mathrm{B}$ ). The $\mathrm{O}_{2}$ mass trace follows this trend, which indicates that an activation process takes place over time. Simultaneously, there is $\mathrm{CO}_{2}$ evolution as well. $\mathrm{CO}_{2}$ is indicative of (oxidative) catalyst degradation. To be sure that $\mathrm{CO}_{2}$ is not originating from the oxidation of a carbon electrode work electrode, a large surface area gold electrode $\left(0.14 \mathrm{~cm}^{2}\right)$ was used as a working electrode (WE) for this experiment. It has been shown that gold itself will not oxidize water to $\mathrm{O}_{2}$ 
below $2.0 \mathrm{~V}$ at $\mathrm{pH} 1{ }^{61}$ Thus, the electrochemically evolved $\mathrm{O}_{2}$ is produced by the complex and/or its degradation products.

Deposition of Material on the Electrode. Electrochemically studied iridium complexes can deposit material on the electrode during catalysis. ${ }^{21,33,45,50,51,56}$ Often, a simple "electrode rinse test" is used to have a quick indication whether a deposit is formed on the electrode. After measuring the complex of interest, the working electrode is rinsed and tested in a catalyst-free electrolyte. Deviations in this CV with respect to the $\mathrm{CV}$ of a freshly polished electrode indicate that material has been (electro)deposited on the electrode. Indeed, for all complexes, the $\mathrm{CV}$ deviated after rinsing the electrode. Specifically, the double layer and maximum current increased significantly for the GC electrodes (for example, see Figure S2 where the $\mathrm{CVs}$ for ${ }^{6-\mathrm{OH}} \mathbf{1}$ are displayed), suggesting that there is electrodeposition in all cases. The produced CVs do not change over the course of five scans, indicating negligible desorption of the deposited layer. Of note, an increased double layer and maximum current could also originate from electrode degradation as carbon electrodes do corrode at high potentials. $^{62}$ The formation of a deposit can be studied in more detail by employing electrochemical quartz crystal microbalance (EQCM) experiments. ${ }^{50,58,63,64}$ For this purpose, a quartz crystal with a deposited gold layer is used as a working electrode. The quartz crystal is oscillated during the course of the experiment. The frequency of this oscillation is dependent on the mass of the electrode. Specifically, a decrease in this frequency corresponds to an increase of mass. Any potentialrelated mass changes of the electrode can thus be revealed while monitoring the relative frequency when cyclic voltammetry is performed. The complexes ${ }^{6-\mathrm{OH}_{1}} \mathbf{1}$ and ${ }^{\mathrm{H}} \mathbf{1}$ were studied with EQCM while performing cyclic voltammetry in a potential window from 1.3 to $1.9 \mathrm{~V}$ (Figure 2). For both complexes, the oscillation frequency decreases while the anodic current increases at potentials above 1.55 for ${ }^{6-\mathrm{OH}} \mathbf{1}$ and $1.65 \mathrm{~V}$ for ${ }^{\mathrm{H}} \mathbf{1}$, which is within the catalytic potential window. Thus, the mass of the electrode increases during the water oxidation reaction, indicating that a deposit is steadily formed on the electrode. In addition, ${ }^{\mathrm{H}} \mathbf{1}$ shows less deposition than ${ }^{6-\mathrm{OH}_{1}}$ over the course of 10 scans. The $\Delta$ frequency reaches $-130 \mathrm{~Hz}$ for ${ }^{\mathrm{H}} 1$ as opposed to $-320 \mathrm{~Hz}$ for ${ }^{6-\mathrm{OH}} 1$ with the lower value being indicative of more deposition. Later, we show that all complexes electrodeposit iridium species by analyzing the electrodes with surface-sensitive X-ray photoelectron spectroscopy (XPS).

Spectroscopic Studies of Electrolyte after Bulk Electrolysis. The electrodeposition of material might be triggered by complex degradation. Several iridium complexes have been reported to (partially) disintegrate under the oxidative conditions under which water oxidation is performed. ${ }^{29,30,33-56}$ Degradation products, such as (colloidal) iridium oxide $\left(\mathrm{IrO}_{x}\right)$, have been observed in studies using sacrificial reagents as well as electrochemical studies. The presence of $\mathrm{IrO}_{x}$ in a solution could be indicated by a distinctive absorption at $580 \mathrm{~nm}$ in the UV-vis spectrum. ${ }^{65,66}$ Of note, an absorption at $580 \mathrm{~nm}$ is not exclusively related to $\mathrm{IrO}_{x}$ but could originate from other iridium species as well. ${ }^{52}$ In addition, $\mathrm{Cp}^{*}$ in the coordination sphere of iridium in $\left[\mathrm{Cp} * \mathrm{IrL}_{n}\right]$ type complexes is not stable under oxidative conditions. $^{29,30,33-47,57}$ The exact mechanism of $\mathrm{Cp}^{*}$ degradation was previously elucidated by Macchioni and co-workers for three $\left[\mathrm{Cp}^{*} \mathrm{IrL}_{n}\right]$ type complexes. ${ }^{30}$ Several Ir-containing intermediates could be characterized, and it was determined that the oxidative degradation of $\mathrm{Cp}^{*}$ eventually leads to acetic, formic, and glycolic acids. To study whether any of these breakdown products are observed, we set out a 6-h bulk electrolysis experiment to allow for nuclear magnetic resonance (NMR) and UV-vis spectroscopy studies of the electrolyte after catalysis. Bulk electrolysis affects the entire electrolyte as opposed to a regular electrochemical setup where merely a small diffusion layer close to the working electrode is reached. To perform bulk electrolysis, a large, custom-made and preanodized glassy carbon work electrode $\left(0.79 \mathrm{~cm}^{2}\right)$ was used as a working electrode to be able to generate as much current as possible in a $6 \mathrm{~h}$ window of the experiment. Preanodization of the electrode was performed by applying 2.1 $\mathrm{V}$ in a catalyst-free electrolyte for $25 \mathrm{~min}$. Furthermore, a $\mathrm{H}$ cell was used allowing for separation of the electrolyte exposed to the working and counter electrodes by a proton conductive Nafion membrane. A potential of $1.9 \mathrm{~V}$ versus RHE was applied for $6 \mathrm{~h}$, while the electrolyte containing $1 \mathrm{mM}$ of ${ }^{4-\mathrm{OH}} \mathbf{1}$ was continuously stirred. Furthermore, $\mathrm{D}_{2} \mathrm{O}$ instead of $\mathrm{H}_{2} \mathrm{O}$ was used to be able to study the electrolyte with ${ }^{1} \mathrm{H}$ NMR. After bulk electrolysis, the intact complex ${ }^{4-\mathrm{OH}_{1}} \mathbf{1}$ was found to be the major compound in the electrolyte according to the NMR studies (Figure S4). However, the observation of unaffected complex cannot be used as an indication of complex stability as not all material might have been in contact with the electrode during the $6 \mathrm{~h}$ experiment. Nonetheless, acetate and other distinctive breakdown products from $\mathrm{Cp}^{*}$ were observed as well. Interestingly, no uncoordinated 4-hydroxypicolinate is observed, suggesting that the ligand is still coordinated to the remaining iridium complex after $\mathrm{Cp}^{*}$ degradation, which is in line with other reports. ${ }^{29,30,33-47,57}$ In fact, the $\mathrm{Cp}^{*}$ degradation bears resemblance to the previously reported degradation of 1 when sacrificial oxidants are used. ${ }^{27,28}$ The UV-vis spectrum of the electrolyte after bulk electrolysis has not changed significantly (Figure S5). Notably, no peak at $580 \mathrm{~nm}$ has emerged, indicating that no $\mathrm{IrO}_{x}$ nanoparticles are present in the solution. As expected, the $\mathrm{CV}$ response of the $\mathrm{GC}$ electrode in a catalyst-free electrolyte has significantly changed with respect to its freshly polished state (Figure S6) due to the deposition of iridium material. The fact that there is no $\mathrm{IrO}_{x}$ in the solution and that 4-hydroxypicolinate can exclusively be assigned to ${ }^{4-\mathrm{OH}_{1}} \mathbf{1}$ indicates that any species that is the result of the degradation of ${ }^{4-\mathrm{OH}} \mathbf{1}$ is either a paramagnetic $\operatorname{Ir}(\mathrm{IV})$ species or has settled on the electrode.

Comparative Chronoamperometry Studies. The Picolinate Catalysts (1). It is difficult to draw conclusions from $\mathrm{CV}$ experiments with $\mathbf{1}$ with respect to the water oxidation reaction because of the simultaneous electrodeposition process. There is a clear negative shift of $0.1 \mathrm{~V}$ in the onset of the anodic current induced by the more electron donating complexes ${ }^{6-\mathrm{OH}} \mathbf{1}$ and ${ }^{4-\mathrm{OH}} \mathbf{1}$. However, the shift in onset is not exclusively related to enhanced water oxidation performance but also to a different amount of electrodeposition. The latter case is illustrated by the unequal amount of material that is electrodeposited by the complexes (Figure 2). Also, the material that deposits in one $\mathrm{CV}$ scan will affect the next $\mathrm{CV}$ scan. Therefore, any apparent difference in the CVs of the complexes (Figure S1) that seems to be performance related might actually be due to inconsistencies caused by electrodeposition (Figure S2). Moreover, the different magnitude of the currents measured in CV experiments with 1 (Figure S1) are actually within the experimental error (Figure S3). 

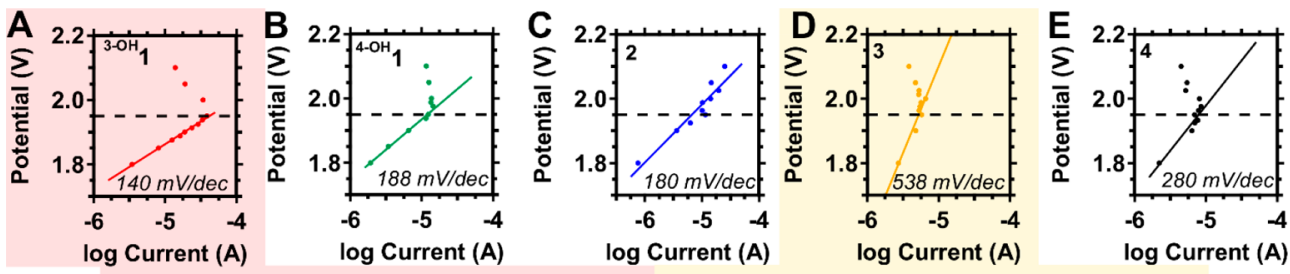

$\mathbf{F}$
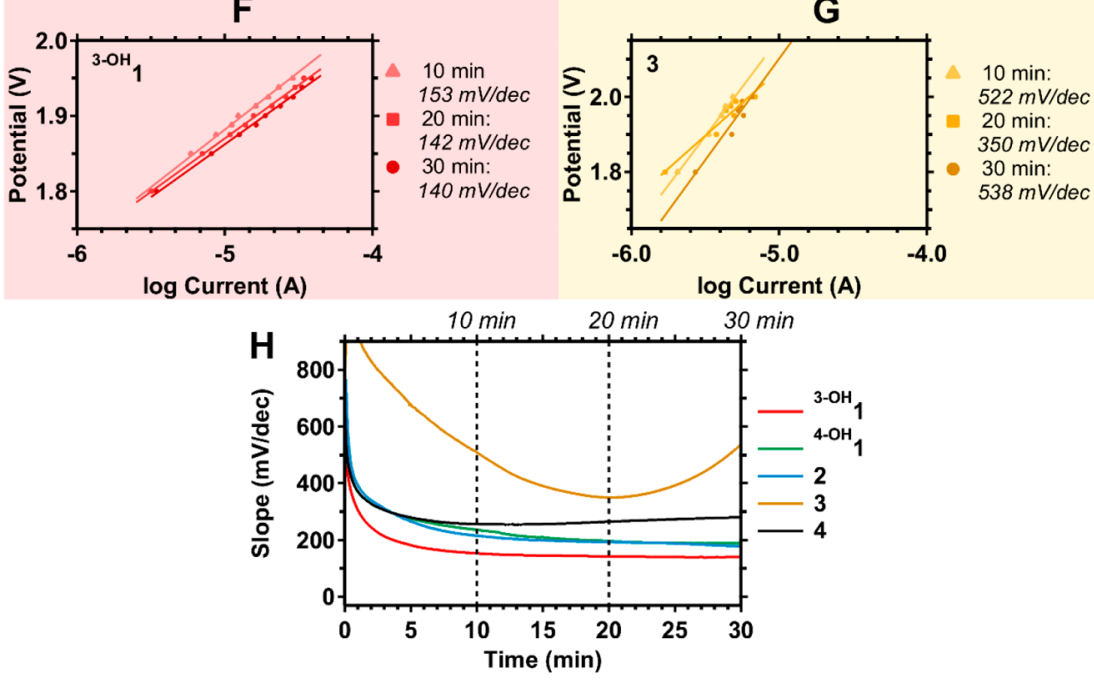

Figure 3. The logarithm of the current after 30 min of amperometry versus the potential for the complexes ${ }^{3-\mathrm{OH}} \mathbf{1}(\mathrm{A}),{ }^{4-\mathrm{OH}} \mathbf{1}(\mathrm{B}), \mathbf{2}(\mathrm{C}), \mathbf{3}$ (D), and 4 (E). The currents were measured with a GC working electrode that was preanodized by applying a potential of $2.1 \mathrm{~V}$ for $25 \mathrm{~min}$ in a complex-free electrolyte. The current generated by this anodized electrode in the absence of complex was used to normalize the currents generated by the complexes. Linear fits (straight lines) have been applied to the potential window that shows an increase in current with increasing potential. Fits of the current after 10, 20, and $30 \mathrm{~min}$ are displayed in $\mathrm{F}\left({ }^{3-\mathrm{OH}} \mathbf{1}\right)$ and $\mathrm{G}(3)$. The lines in $\mathrm{H}$ represent the slope of this fit of complexes $\mathbf{1 - 4}$ and its magnitude over time to illustrate the continuous change.

Furthermore, glassy carbon electrodes are oxidized at high potentials. $^{62}$ This process is reflected in an amperogram by an initial increase of the current until a maximum is reached (Figure S7). Subsequently, the current decreases slightly to a stable, plateauing current. This process is faster at higher potentials. The magnitude of GC anodization is similar to the magnitude of the currents generated by the complexes under our conditions (Figure S7A-D). Also, in some cases, we observed that the current could suddenly increase to a higher plateauing level. An example can be found in the amperogram of ${ }^{3-\mathrm{OH}} 1$ recorded at $2.1 \mathrm{~V}$ (Figure S7D). This artifact could not be reproduced when a fresh solution of ${ }^{3-\mathrm{OH}_{1}}$ was measured twice (Figure S8). Instead, the magnitude of the current differed for both measurements. The undesirable changes in surface structure of the GC electrode during anodic corrosion was found as a source of these phenomena.

We therefore studied the most electron poor $\left({ }^{3-\mathrm{OH}} \mathbf{1}\right)$ and electron rich $\left({ }^{4-\mathrm{OH}} \mathbf{1}\right)$ hydroxypicolinate complexes with an elaborate chronoamperometry study which resulted in reproducible data. Moreover, chronoamperometry can visualize processes such as deactivation or activation over time and allows for a better comparison. ${ }^{56}$ Specifically, PEEK encapsulated GC electrodes were used to establish that the same geometrical surface area $\left(0.07 \mathrm{~cm}^{2}\right)$ is exposed to the electrolyte. Furthermore, the GC electrode was preanodized at $2.1 \mathrm{~V}$ for $25 \mathrm{~min}$ in a complex-free $\mathrm{pH} 7$ phosphate buffer. This preanodization treatment ensures that the GC electrode generates a stable, plateauing current at all relevant potentials in the absence of a catalyst. ${ }^{62}$ Next, a 10 min amperogram was taken of the GC electrode at the desired potential and used for background correction. Finally, a $30 \mathrm{~min}$ amperogram was recorded in the electrolyte containing the complex at the desired potential. This process was repeated for each potential that was measured. In an ideal case, the obtained current under steady state conditions is purely kinetic in nature, thus controlled by the catalytic mechanism of the catalyst. A straight line is expected when the potential is plotted versus the log of the current. The slope of this fitted line can subsequently be used to compare differences in activity and mechanism. ${ }^{67}$ In our case, the magnitude of the slope is not only dependent on the kinetics of water oxidation but also on mass-transport limitations of the parent complex to the electrode and the kinetics of electrodeposition. Therefore, obtaining direct mechanistic information about water oxidation remains elusive using this method. To start, the background-corrected current that was generated by ${ }^{3-\mathrm{OH}} \mathbf{1}$ and ${ }^{4-\mathrm{OH}_{1}} \mathbf{1}$ after $30 \mathrm{~min}$ of amperometry is plotted versus the potential in Figure $3 \mathrm{~A}$ and B. Notably, the currents at lower potential (below $1.95 \mathrm{~V}$ ) can be fitted with a straight line with a positive slope. The currents at higher potential do not follow this trend. The course of the generated currents of the raw amperograms are also potential dependent (Figure S9). Applying potentials below $1.95 \mathrm{~V}$ resulted in generated currents that slowly increase over time. In contrast, the magnitude of the current generally reaches a maximum and decreases subsequently over time at potentials above $1.95 \mathrm{~V}$. The behavior of the current over time might be related to a change in mechanism of the water oxidation reaction, electrodeposition, or a combination thereof. Alternatively, potential dependent aggregation of catalytic particles, thereby reducing the number of active sites, may be an 
explanation for the kink in the log current versus potential profiles. Second, we found that the slope of the fit is not constant but changes over time. As illustrated in Figure $3 \mathrm{~F}$ for ${ }^{3-\mathrm{OH}} \mathbf{1}$, the slope of the fit has a different value after 10,20 , or $30 \mathrm{~min}$ of chronoamperometry. The continuous change of this fitted slope over time is displayed in Figure $3 \mathrm{H}$ for the full time scale of the experiment $(30 \mathrm{~min})$. For both ${ }^{3-\mathrm{OH}} \mathbf{1}$ and ${ }^{4-\mathrm{OH}} \mathbf{1}$, the magnitude of the slope starts at a high value but decreases over time and reaches a constant value. The slope of ${ }^{3-\mathrm{OH}_{1}}$ decreases more quickly and reaches a lower value $(140 \mathrm{mV} /$ dec) as compared to ${ }^{4-\mathrm{OH}} \mathbf{1}(188 \mathrm{mV} / \mathrm{dec})$. This observed difference might be related to the structural difference of the parent complexes. However, the water oxidation activity of ${ }^{3-\mathrm{OH}_{1}}$ and ${ }^{4-\mathrm{OH}_{1}}$ after $30 \mathrm{~min}$ is on the same order of magnitude where the highest obtained currents are $0.59 \mathrm{~mA}$ $\mathrm{cm}^{-2}\left({ }^{3-\mathrm{OH}} \mathbf{1}\right)$ and $0.30 \mathrm{~mA} \mathrm{~cm}{ }^{-2}\left({ }^{4-\mathrm{OH}} \mathbf{1}\right)$. This is in contrast to the large difference in activity found in the preceding studies at pH 7 with $\mathrm{NaIO}_{4}$ as a sacrificial oxidant. ${ }^{28}$ In that study, turnover frequencies (TOF) up to $300 \mathrm{~min}^{-1}$ were found for ${ }^{3-\mathrm{OH}_{1}}$ as opposed to a TOF of around $60 \mathrm{~min}^{-1}$ found for ${ }^{4-\mathrm{OH}} \mathbf{1}$.

Extension of Studies to 2-4. To place the structureactivity relationship of ${ }^{3-\mathrm{OH}} \mathbf{1}$ and ${ }^{4-\mathrm{OH}} \mathbf{1}$ into a broader perspective, we initially screened the iridium complexes $2-5$ (Chart 1) that have more profound modifications of the ligand system. $[\mathrm{Cp} * \operatorname{Ir}($ pyalc $)(\mathrm{Cl})](2)^{14,37,43,44,50}$ was chosen as the well-known example of a complex that degrades by losing $\mathrm{Cp}^{*}$ but forms a homogeneous, dinuclear homogeneous catalyst still bearing its bidentate ligand. 2 can be transformed to the active species by either $\mathrm{NaIO}_{4}$ or by electrolysis with gold electrodes above $1.5 \mathrm{~V}$ versus RHE in $\mathrm{Na}_{2} \mathrm{SO}_{4}$ solutions of $\mathrm{pH}$ $2-3$. The bidentate pyalc ligand of 2 bears structural similarities to the hydroxypicolinate ligands of $\mathbf{1}$. [Ir(ppy $)_{2}\left(\mathrm{H}_{2} \mathrm{O}\right)_{2}$ ]OTf $(3)^{15}$ was chosen as a benchmark for a homogeneous iridium complex that does not contain $\mathrm{Cp}^{*}$ and performs CAN driven water oxidation. $\left[\mathrm{Cp}^{*} \operatorname{Ir}\left(\mathrm{H}_{2} \mathrm{O}\right)_{3}\right]$ $\left(\mathrm{NO}_{3}\right)_{2}(4)^{16,17}$ has no ligand apart from $\mathrm{Cp}^{*}$ and is known to lead to electrochemical $\mathrm{IrO}_{x}$ deposition at potentials above $1.3 \mathrm{~V}$ versus $\mathrm{RHE}$ in $\mathrm{KNO}_{3}$ solution of $\mathrm{pH} 3 .{ }^{33,50}$ In addition, $\mathrm{K}\left[\mathrm{Ir}(\right.$ picolinate $\left.)\left(\mathrm{Cl}_{3}\right)(\mathrm{MeOH})\right](5)$ is a $\mathrm{Cp}^{*}$ lacking complex that electrochemically oxidizes to deposit $\mathrm{IrO}_{x}{ }^{56}$ In that study, the amount of $\mathrm{IrO}_{x}$ deposit was below the detection limit of EQCM but could be determined with XPS. Water oxidation started with a considerable lag time after the oxidative conversion of $\mathbf{5}$. In turn, the lag time was potential dependent: at $2.0 \mathrm{~V}, \mathrm{O}_{2}$ evolution started after $32 \mathrm{~s}$, whereas the lag time was $82 \mathrm{~s}$ at a potential of $1.9 \mathrm{~V}$. Also, the highest activity was found at $\mathrm{pH} 1$, while at $\mathrm{pH} 7$ only negligible activity was observed. $^{56}$

First of all, we screened complexes $\mathbf{1 - 5}$ by performing chronoamperometry at $1.8,1.9,2.0$, and $2.1 \mathrm{~V}$ under the exact same conditions, specifically at $\mathrm{pH} 7$ in a $0.1 \mathrm{M}$ phosphate buffer. Of note, these conditions are different from the conditions that have been previously reported for complexes 1-5. We found that the water oxidation activity of all complexes is within the same order of magnitude (Figure $\mathrm{S} 7 \mathrm{E}-\mathrm{H}$ ) under our conditions. Also, there is no clear structure-activity relationship. 5 was excluded from further studies since the activity was marginal, similar to the findings of previous studies at this $\mathrm{pH} .{ }^{56}$ We further subjected $2-4$ to the elaborate chronoamperometry study as performed for ${ }^{3-\mathrm{OH}} \mathbf{1}$ and ${ }^{4-\mathrm{OH}} \mathbf{1}$. The resulting logarithms of current versus potential are displayed in Figure 3C-E. The highest produced current densities of the complexes are close together in a range from $0.2-0.6 \mathrm{~mA} \mathrm{~cm}{ }^{-2}\left(3-{ }^{3-\mathrm{OH}} \mathbf{1}\right)$. Similar to ${ }^{3-\mathrm{OH}_{1}} \mathbf{1}$ and ${ }^{40 \mathrm{H}} \mathbf{1}$, we found that the fitted slope changes over time. Especially 3 displays large shifts as illustrated in Figure $3 \mathrm{G}$ and $\mathrm{H}$. At first sight, the difference between the picolinate series and $\mathbf{2}$ is rather small. Specifically, the magnitude of the fitted slope for 2 (Figure 3C) as well as the progression of the slope over time (Figure $3 \mathrm{H}$ ) are similar to that of ${ }^{4-\mathrm{OH}} \mathbf{1}$. This might be related to the more electron-donating character of both ligands relative to that of ${ }^{3-\mathrm{OH}} \mathbf{1}$. Unlike ${ }^{3-\mathrm{OH}} \mathbf{1}$ and ${ }^{4-\mathrm{OH}} \mathbf{1}$, there is no kink in the data above $1.95 \mathrm{~V}$ (Figure 3C). Instead, the current increases with increasing potential within the full potential window of 1.8 to $2.1 \mathrm{~V}$. In contrast, $\mathrm{Cp}^{*}$-free 3 and $\mathrm{IrO}_{x}$ forming 4 show more profound differences. The fitted slopes are higher (Figures $3 \mathrm{D}$ and $\mathrm{E}$ ), and the progress of the slope over time is different as compared to $\mathbf{1}$ and $\mathbf{2}$ (Figures $3 \mathrm{~F}$ and $\mathrm{G}$ and $\mathrm{H}$ ). Specifically, the magnitude of the slope of 4 quickly decreases to a minimum value and subsequently increases slowly. The slope is far higher than that found for $\mathrm{IrO}_{2}$ nanoparticles, ${ }^{68}$ possibly due to the interplay of simultaneous deposition, degradation, activation, and water oxidation under these conditions. The fitted slope of $\mathbf{3}$ follows the same trend as $\mathbf{4}$ over time, but the magnitude is higher at all points in time than any of the other catalysts. The large difference displayed by 3 with respect to 1, 2, and 4 might indicate that the absence of $\mathrm{Cp}^{*}$ or the presence of two ligands in the parent complex plays a role. The difference in the progression of the slope of 4 with respect to $\mathbf{1}$ and $\mathbf{2}$ over a longer period of time could be caused by the additional presence or absence of a bidentate ligand in combination with $\mathrm{Cp}^{*}$ as a ligand, but the differences are less clear. Moreover, the fitted slope that is used here in the analysis is dependent on the kinetic OER, the deposition of catalytic material, and the mass transport of fresh material to the electrode. Therefore, any differences cannot be unambiguously linked to underlying mechanisms based on the structural differences of the parent complexes.

X-ray Photoelectron Spectroscopy of Complexes 1-4 and Their Respective Deposition. Spectra of Parent Complexes 1-4. The previous experiments strongly suggest the formation of an iridium containing surface-deposit on the electrode that is able to catalyze the water oxidation reaction. Surface-sensitive X-ray photoelectron spectroscopy (XPS) was employed to investigate the nature of these depositions. In addition, XPS can provide information on the electronic environment and any trends therein. The Ir $4 \mathrm{f}$ region including both spin-orbit split peaks is displayed in Figure 4. For the parent complex ${ }^{3-\mathrm{OH}} 1$, an iridium species with a binding energy (BE) of $62.3(1) \mathrm{eV}$ was found in the $\operatorname{Ir} 4 \mathrm{f}_{7 / 2}$ spectrum. For ${ }^{4-\mathrm{OH}} 1$, a species with a lower binding energy of $62.1(1) \mathrm{eV}$ was observed. As expected, the iridium species of ${ }^{3-\mathrm{OH}_{1}}$ has a slightly higher binding energy as the electron density around the metal ion is lower due to the more electron-withdrawing nature of the picolinate ligand as compared to ${ }^{4-\mathrm{OH}} \mathbf{1}$. In contrast, the pyridinic ligand of $\mathbf{2}$ has a more electron donating character with respect to both picolinate ligands. Indeed, an Ir $4 \mathrm{f}_{7 / 2}$ species at a lower binding energy of $61.7 \mathrm{eV}$ was found for complex 2 that is in line with a more electron rich metal center. Analogous to 2, an Ir $4 \mathrm{f}$ species at $61.7 \mathrm{eV}$ is found for complex 3. The identical binding energies indicate that the iridium metal centers are in the same electronic state. Even though $\mathrm{Cp}^{*}$ is absent in complex 3 , the two bidentate ligands apparently have a similar electronic character to that of the 


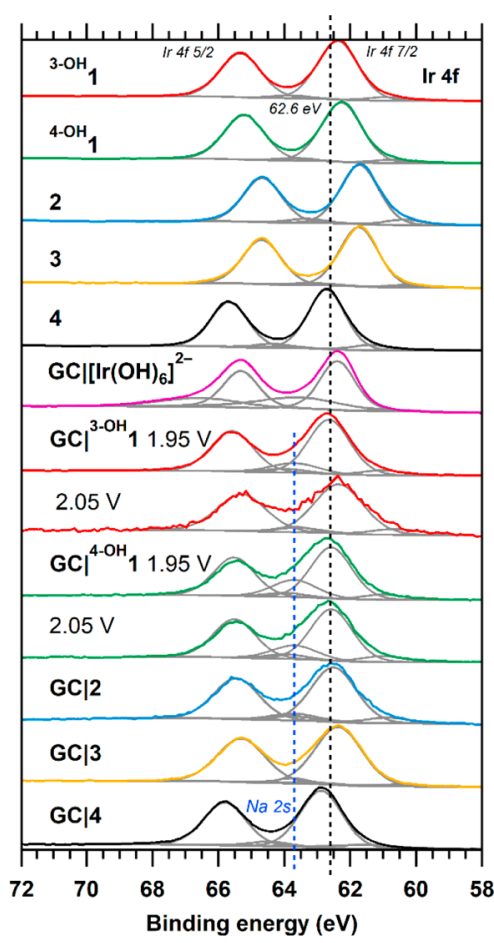

Figure 4. XPS spectra of the Ir $4 \mathrm{f}$ region of the compounds ${ }^{3-\mathrm{OH}_{1}}$ (red), ${ }^{4-\mathrm{OH}} \mathbf{1}$ (green), 2 (blue), $\mathbf{3}$ (orange), and $\mathbf{4}$ (black) as well as that of the electrodes subjected to $\mathrm{CA}$ in the presence of the complex at $1.95 \mathrm{~V}$ for $30 \mathrm{~min}: \mathbf{G C l}^{3-\mathrm{OH}} \mathbf{1},\left.\mathbf{G C l}\right|^{4-\mathrm{OH}} \mathbf{1}, \mathbf{G C l} \mathbf{2}, \mathbf{G C l} 3$, and $\mathbf{~ G C l} \mathbf{4}$ or at $2.05 \mathrm{~V}$ for $\mathbf{G C l}^{3-\mathrm{OH}_{1}} \mathbf{1}$ and $\mathbf{G C l}^{4-\mathrm{OH}} \mathbf{1}$. In gray, the fitted species are shown.

combined ligand system of $\mathbf{2}$. Complex 4 lacks any ligands apart from $\mathrm{Cp}^{*}$. This results in an iridium center that is relatively electron poor with respect to 1 and 2; an Ir $4 \mathrm{f}$ species with a higher binding energy of $62.7 \mathrm{eV}$ is found. For all complexes, species in the $\mathrm{N}$ 1s XPS spectrum are observed as well (Figure $\mathrm{S} 10 \mathrm{~A}$ ). For ${ }^{3-\mathrm{OH}} \mathbf{1}$ and ${ }^{4-\mathrm{OH}} \mathbf{1}$, two major species can be found at $406.4 \mathrm{eV}$ and $400.2\left({ }^{3-\mathrm{OH}_{1}} \mathbf{1}\right)$ or $399.7 \mathrm{eV}$ $\left({ }^{4-\mathrm{OH}} \mathbf{1}\right)$. The electronically poor nitrogen of $\mathrm{NO}_{3}{ }^{-}$corresponds to the first species, whereas the pyridinic nitrogen of the picolinate ligand corresponds to the lowest binding energies. Clearly, the electronic effect of the position of the hydroxyl substituent is reflected in the difference in binding energies. Logically, the more electron rich nitrogen of the picolinate ligand of ${ }^{4-\mathrm{OH}_{1}} 1$ has a lower binding energy. 2 does not contain $\mathrm{NO}_{3}{ }^{-}$but does show a peak for the pyridinic nitrogen at 399.8 $\mathrm{eV}$. The electron donating character of the pyridinic ligand of 2 is mostly due to the isopropyl bridged alcohol that coordinates to the metal center. Thus, the pyridinic nitrogen of 2 has a similar electronic level $(399.8 \mathrm{eV})$ as compared to ${ }^{4-\mathrm{OH}} \mathbf{1}$. This is also the case for 3 where the pyridinic nitrogen is not the most electron donating moiety and has a binding energy of $400.3 \mathrm{eV}$. The electron donating moiety of the ligand system of 3 is the organometallic $\mathrm{Ir}-\mathrm{C}$ bond. 4 does not have a pyridinic nitrogen. Instead, the nitrate ions observed at $406.6 \mathrm{eV}$ are close to the $406.4 \mathrm{eV}$ found for ${ }^{3-\mathrm{OH}} \mathbf{1}$ and ${ }^{4-\mathrm{OH}} \mathbf{1}$. Additionally, in all the $\mathrm{N} 1 \mathrm{~s}$ spectra of the nitrate containing complexes ${ }^{3-\mathrm{OH}_{1}} \mathbf{1},{ }^{4-\mathrm{OH}} \mathbf{1}$, and 4 , there is an additional nitrogen species observed at $403.7 \mathrm{eV}$ which we cannot assign at this point. The $\mathrm{O}$ 1s spectrum was also recorded for all complexes (Figure S10B). The different oxygen moieties found in the ligand systems for 1-4 cannot be precisely assigned due to overlapping signals in the recorded spectra. For instance, the oxygen of nitrate might be found at binding energies ranging from 531 to $534 \mathrm{eV}^{69}$ that fully overlap with the observed $\mathrm{O} 1 \mathrm{~s}$ signal. Only for 2, there is a major species at a lower binding energy of $529.6 \mathrm{eV}$. This low binding energy indicates an electron-rich oxygen moiety and can be assigned to the metalcoordinated alcohol of the pyridinic ligand of 2. Overall, the trend of the electronic state of iridium and nitrogen species of complexes 1-4 observed in the XPS spectra is in line with the expected trend in structurally induced electronegativity of the ligand.

Spectra of Deposited Species on GCl1-GCl4. In all prolonged chronoamperometry experiments with $1-4$, a blue deposit was formed on the GC electrodes. As discussed, EQCM studies for ${ }^{\mathrm{H}} \mathbf{1}$ and ${ }^{6-\mathrm{OH}} \mathbf{1}$ showed that electrodeposition accompanies the electrochemical water oxidation. We used XPS to study the surface of GC electrodes after chronoamperometry was performed in solutions containing 1-4. In detail, these samples are GC electrodes that have been preanodized at $2.1 \mathrm{~V}$ and subsequently been used to perform CA at $1.95 \mathrm{~V}$ in a solution containing the catalyst. For reference, the XPS spectra of a preanodized GC electrode were recorded as well (Figure S11). The $\mathrm{N}$ 1s regions and $\mathrm{O} 1 \mathrm{~s}$ regions showed that this preanodized electrode surface contains nitrogen and oxygen moieties. In fact, the $\mathrm{N} 1 \mathrm{~s}$ and $\mathrm{O} 1 \mathrm{~s}$ spectra of all investigated preanodized GC electrodes are dominated by these species (Figure S10). These spectra can thus not be used to find traces of ligand (residues) on the electrodes. XPS analysis of the Ir $4 \mathrm{f}$ region of the anodized electrode (Figure S11) revealed the presence of a $\mathrm{Na} 2 \mathrm{~s}$ species with a binding energy of $63.7 \mathrm{eV}$ because the $\mathrm{Na} 2 \mathrm{~s}$ and Ir $4 \mathrm{f}$ regions overlap. Apparently, the preanodization treatment results in the deposition/entrapment of sodium from the electrolyte on the surface of the GC electrode. This sodium species is present in the spectra of all the electrodes (Figure 4). The Na 2s species is only a minor component in the Ir $4 \mathrm{f}$ spectrum, and thus iridium species can readily be observed and fitted (Figure 4). Sample $\mathbf{G C l}^{3-\mathrm{OH}} \mathbf{1}$ is a preanodized GC electrode used to perform chronoamperometry in a solution containing ${ }^{3-\mathrm{OH}} \mathbf{1}$ at either 1.95 or $2.05 \mathrm{~V}$. At both potentials, there is a typical iridium doublet signal in the Ir $4 \mathrm{f}$ region as well as a sodium species originating from the preanodization of the GC electrode (Figure 4). A second, minor iridium species could be fitted as well. So, there must be a deposit of some sort of iridium species on the electrode. Interestingly, the surface of $\mathbf{G C l}^{4-\mathrm{OH}} \mathbf{1}$ contains the same major $(62.6 \mathrm{eV})$ and minor $(60.9 \mathrm{eV})$ iridium species as $\mathbf{G C l}^{3-\mathrm{OH}} \mathbf{1}$ in the $\operatorname{Ir} 4 f_{7 / 2}$ spectrum. Moreover, the applied potential (1.95 or $2.05 \mathrm{~V}$ ) during chronoamperometry has no influence on the binding energy of these deposited iridium species. Notably, the binding energies of the major and minor iridium species of $\mathbf{G C l}^{3-\mathrm{OH}} \mathbf{1}$ and $\mathrm{GCl}^{4-\mathrm{OH}} \mathbf{1}$ do not match with the binding energy of iridium in the respective parent complexes ${ }^{3-\mathrm{OH}_{1}} \mathbf{1}$ and ${ }^{4-\mathrm{OH}} \mathbf{1}$. The electrodes used for chronoamperometry at $1.95 \mathrm{~V}$ in the presence of complexes 2-4 (GCl2-GCl4) show deposited iridium species on the surface as well. The surface of $\mathbf{G C l} 2$ contains a species with a $\mathrm{BE}$ of $62.6 \mathrm{eV}$. This $\mathrm{BE}$ is identical to that of the iridium species on $\mathrm{GCl}^{3-\mathrm{OH}} 1$ and $\mathrm{GCl}^{4-\mathrm{OH}} \mathbf{1}$ but does not match the parent complex 2 . The deposited iridium species on $\mathbf{G C l} 3$ has a slightly lower BE of $62.4 \mathrm{eV}$, whereas GCl4 has a deposited species with a higher BE of $62.9 \mathrm{eV}$. Overall, the difference in $\mathrm{BE}$ of the deposited $\mathrm{Ir} 4 \mathrm{f}$ species on the GC electrodes is smaller than the difference in $\mathrm{BE}$ of the parent complexes. Thus, the ligand of the parent complex barely 
influences the electronic state of iridium in the deposit as opposed to its effect on the parent complexes.

Activity and XPS Analysis of IrO $_{x}$ Deposited by $\left[\operatorname{Ir}(\mathrm{OH})_{6}\right]^{2-}$ and IrO $_{x}$ Nanoparticles. Water Oxidation Activity. $\mathrm{IrO}_{x}$ nanoparticles are sometimes suggested or observed to be the active water oxidation species. Therefore, we tested the electrochemical water oxidation activity of these nanoparticles. Either as an electrodeposited in situ formed layer on the electrode surface or as a colloidal $\mathrm{IrO}_{x}$ solution. $\left[\operatorname{Ir}(\mathrm{OH})_{6}\right]^{2-}$ is a precursor for the generation of thin nanoparticle films of $\mathrm{IrO}_{x}$ by electrodeposition. ${ }^{66}$ An exact $\mathrm{pH}$ of 12.1 is required in the preparation of a $2 \mathrm{mM}$ $\left[\operatorname{Ir}(\mathrm{OH})_{6}\right]^{2-}$ solution as otherwise a deep blue, colloidal solution of $\mathrm{IrO}_{x}$ nanoparticles is obtained. Specifically, $\mathrm{pH} 12.1$ corresponds to a concentration of $12 \mathrm{mM}$ of $\mathrm{OH}^{-}$required for the hydrolysis of $2 \mathrm{mM} \mathrm{K} \mathrm{IrCl}_{6}$ to a $2 \mathrm{mM}$ solution of $\left[\operatorname{Ir}\left(\mathrm{OH}_{6}\right)\right]^{2-}$. Both solutions $\left(\left[\operatorname{Ir}(\mathrm{OH})_{6}\right]^{2-}\right.$ and colloidal $\left.\mathrm{IrO}_{x}\right)$ were tested for their water oxidation activity. These solutions yield a black precipitate when mixed with phosphate buffer. Therefore, electrochemical tests were performed with $0.5 \mathrm{M}$ $\mathrm{NaClO}_{4}$ as the supporting electrolyte. The water oxidation currents that were obtained with a GC electrode in these solutions (containing $1 \mathrm{mM}$ iridium) were 2 orders of magnitude higher than those obtained with 1-5 (Figures S12 and S7). Bubble formation is clearly observed and causes noisy amperograms (Figure S12). Moreover, maximum activity is obtained at $1.9 \mathrm{~V}$ for $\left[\mathrm{Ir}(\mathrm{OH})_{6}\right]^{2-}$ with currents reaching up to $11 \mathrm{~mA} \mathrm{~cm}{ }^{-2}$. The colloidal $\mathrm{IrO}_{x}$ solution produces lower currents with a maximum of $4 \mathrm{~mA} \mathrm{~cm}{ }^{-2}$ at $1.8 \mathrm{~V}$. Remarkably, at higher potentials $(2.0$ and $2.1 \mathrm{~V})$, the activity dramatically declines and becomes an order of magnitude lower at $2.1 \mathrm{~V}$ for both $\left[\operatorname{Ir}(\mathrm{OH})_{6}\right]^{2-}$ and colloidal $\mathrm{IrO}_{x}$. This apparent potential related maximum in activity is similar to what is observed for the catalysts 1, 3, and 4 (Figure 3), but not $\mathbf{2}$. Furthermore, the water oxidation activity increases over time, in particular for $\left[\operatorname{Ir}(\mathrm{OH})_{6}\right]^{2-}$ (Figure S12A). In a solution of colloidal $\mathrm{IrO}_{x}$ as well as in a $\left[\operatorname{Ir}(\mathrm{OH})_{6}\right]^{2-}$ solution, a deposit is formed on the electrode while performing chronoamperometry. This electrodeposition becomes evident from the electrode rinse test when pre- and post-CVs are compared (Figure S12C and D). These $\mathrm{CVs}$ after amperometry in Figure S12C and D have similar features and reach currents up to $36 \mathrm{~mA} \mathrm{~cm}^{-2}$ at $2.1 \mathrm{~V}$. Only the first scan of the electrode tested in the colloidal $\mathrm{IrO}_{x}$ solution (Figure S12D) deviates as it has an additional oxidative event at $1.6 \mathrm{~V}$. In terms of water oxidation activity, the $\mathrm{IrO}_{x}$ depositions produce 1 to 2 orders of magnitude higher currents than GCl1-GCl4. The formation of a deposit from a $\left[\mathrm{Ir}(\mathrm{OH})_{6}\right]^{2-}$ solution is also dependent on the aging of the solution. When the solution is a day old, deposition and catalytic water oxidation start immediately after a potential is applied (Figure S12A). However, a considerable lag time of 45 min is observed between the application of $1.95 \mathrm{~V}$ on the GC electrode and the start of the catalytic current (Figure S12E) in a $\left[\operatorname{Ir}(\mathrm{OH})_{6}\right]^{2-}$ solution just $1.5 \mathrm{~h}$ after its preparation. Moreover, the lag time decreases with increasing aging of the solution (Figure S12E). This suggests that the concentration of the species responsible for depositing the active species on the GC electrode slowly increases over time. It is very likely that a small $\mathrm{IrO}_{x}$ cluster is boosting deposition and water oxidation in this case, as a fresh solution initially contains $\left[\operatorname{Ir}(\mathrm{OH})_{6}\right]^{2-}$ but over time gradually contains large colloidal $\mathrm{IrO}_{x}$ particles. ${ }^{66}$ The color change of the solution from colorless to purplish blue over the course of these experiments strengthens this hypothesis. When $1 \mathrm{mM}$ of ligand (4-hydroxypicolinic acid in particular) is added, the solution turns slightly turbid and green. Comparing the amperogram of a $\left[\operatorname{Ir}(\mathrm{OH})_{6}\right]^{2-}$ solution with and without this ligand (Figure S12F) reveals that the lag time decreases in the presence of the ligand but the obtained water oxidation current is a fraction of what is obtained without ligand ( 0.7 versus $5.0 \mathrm{~mA} \mathrm{~cm}{ }^{-2}$ respectively), which is partly due to formation of a black precipitate.

Comparison of Electrode Surface to GC|1-GC|4. XPS was performed on a preanodized electrode on which a potential of $1.95 \mathrm{~V}$ was applied for $1 \mathrm{~h}$ and $15 \mathrm{~min}$ in a $\left[\operatorname{Ir}(\mathrm{OH})_{6}\right]^{2-}$ solution $1.5 \mathrm{~h}$ after its preparation. The spectrum of $\mathrm{GCl}$ $\left[\operatorname{Ir}(\mathrm{OH})_{6}{ }^{2-}\right.$ reveals that two iridium species are deposited on the surface. An $\mathrm{Ir} 4 \mathrm{f}_{7 / 2}$ species with a binding energy of $62.4 \mathrm{eV}$ and a species with a higher binding energy of $63.6 \mathrm{eV}$ were found in a 1.8:1 ratio, respectively. The thickness of the iridium layer is further reflected by the low intensity of the $\mathrm{N}$ 1 s signal at $400.4 \mathrm{eV}$ originating from the anodized GC electrode (Figure S10a). Interestingly, the $\mathrm{Ir} 4 \mathrm{f}_{7 / 2}$ signal of bulk $\mathrm{IrO}_{x}$ is usually reported at a binding energy of 61.8-61.9 eV. ${ }^{70,71}$ However, the "hydration level" of bulk $\mathrm{IrO}_{x}$ has been shown to increase the binding energy of the surface Ir up to binding energies of $62.4-62.5 \mathrm{eV}$, which agrees well with the $62.4 \mathrm{eV}$ species found for $\operatorname{GCl} \operatorname{Ir}(\mathrm{OH})_{6}{ }^{2-71}$ Moreover, this $62.4 \mathrm{eV}$ Ir species has the same the binding energy as the Ir species of GCl3. In contrast, 4 has been reported as $\mathrm{IrO}_{x}$ depositing precatalyst but deposits Ir species at a significantly higher binding energy of $62.9 \mathrm{eV}$ as found for GCl4. ${ }^{33,50}$ This might be due to a different electrochemical treatment (potential of $1.3 \mathrm{~V}$ versus RHE in a $0.1 \mathrm{M} \mathrm{KNO}_{3}$ solution of $\mathrm{pH} 2.9$ ) as compared to previous reports or, more likely, due to remainders of the $\mathrm{Cp}^{*}$ moiety since $9 \%$ of the electrodeposit was found to contain carbon in the same study under those conditions. ${ }^{32}$ Moreover, remainders of the $\mathrm{Cp} *$ ligand might diminish the activity of the electrodeposit as we have found 2 orders of magnitude higher activities with the ligand free $\left[\operatorname{Ir}(\mathrm{OH})_{6}\right]^{2-}$ precursor. Interestingly, the $\mathrm{BE}$ of the minor Ir species at $63.6 \mathrm{eV}$ of $\operatorname{GCl} \operatorname{Ir}(\mathrm{OH})_{6}{ }^{2-}$ is higher than any of the other observed species and falls in the range of $\operatorname{Ir}(\mathrm{IV})$ salts. ${ }^{69}$ In our case, XPS cannot give conclusive distinction between bulk $\mathrm{IrO}_{x}, \mathrm{IrO}_{x}$ with ligand residues, or a different, ligandcontaining species. First of all, $\left[\operatorname{Ir}(\mathrm{OH})_{6}\right]^{2-}$ can only be generated in solution and not isolated as a solid, so the binding energy of the iridium species prior to catalysis cannot be determined. Second, the $\operatorname{Ir} 4 \mathrm{f}_{7 / 2}$ binding energy of bulk $\operatorname{IrO}_{x}$ species can differ as mentioned before and thus cannot be compared directly. However, based on the electrochemical data, it can be concluded that the ligand systems of 1-4 significantly reduce the water oxidation activity of their respective iridium deposit and/or decrease the amount of electrodeposited active iridium sites as compared to the ligandfree iridium precursor $\left[\operatorname{Ir}(\mathrm{OH})_{6}\right]^{2-}$.

Nature of Active Species Generated by 1-5. It is not a new phenomenon that parent iridium complexes (partially) disintegrate like $\mathbf{1 - 5}$ to a catalytically active deposit. $^{29,30,33-47,57}$ It has been suggested that $\mathrm{Cp}^{*}$ based iridium complexes lacking a bidentate ligand degrade to an $\operatorname{IrO}_{x}$ layer. ${ }^{29,33,38}$ In contrast, iridium complexes bearing $\mathrm{Cp}^{*}$ and bidentate ligands may only oxidatively lose $\mathrm{Cp}^{*}$ and produce a dinuclear species as active species for water oxidation. ${ }^{14,36-38,40,44,54,55}$ Acetic acid liberated by $\mathrm{Cp}^{*}$ degradation is suggested to prevent $\mathrm{IrO}_{x}$ formation in that case. ${ }^{72}$ Nonetheless, in some cases, $\mathrm{IrO}_{x}$ nanoparticles were still 
reported despite the presence of bidentate bipyridine ligands. ${ }^{35,46}$ Indeed, we observed $\mathrm{Cp} *$ degradation for ${ }^{4-\mathrm{OH}_{1}}$ under our conditions. The bidentate hydroxypicolinate ligand (or a residue thereof) could be part of the electrodeposit as there was no indication of noncoordinated hydroxypicolinate ligand in the electrolyte afterward. XPS spectroscopy confirmed the deposition of iridium, but the possible presence of a ligand (or residues thereof) remains elusive due to interference of the electrode material in the C 1s spectrum. Nevertheless, the effect of structural diversity of the ligands of $\mathbf{1 - 5}$ on their respective water oxidation activity is marginal. Our chronoamperometry data show that there is no clear relationship between the water oxidation activity of the electrodeposit and the ligand system of the parent complex.

The catalytic behavior of all molecular iridium complexes over time appears to be quite similar under our conditions, yet considerably less active than $\operatorname{IrO}_{x}$ generated from $\left[\operatorname{Ir}(\mathrm{OH})_{6}\right]^{2-}$. Given the complexity of the system, it is difficult to assign the catalytic activity to one predominant species. Nevertheless, we cannot rule out that the same active species is formed for all the complexes 1-5, albeit at significant, larger amounts in the case of $\left[\operatorname{Ir}(\mathrm{OH})_{6}\right]^{2-}$. The organic ligands of $\mathbf{1 - 5}$ as well as the $\mathrm{Cp} *$ degradation products prevent or slow down the formation of $\mathrm{IrO}_{x}{ }^{72}$ The lag time observed for water oxidation with freshly prepared solutions of $\left[\operatorname{Ir}(\mathrm{OH})_{6}\right]^{2-}$ indicates that $\left[\operatorname{Ir}(\mathrm{OH})_{6}\right]^{2-}$ itself is not the depositing species. Instead, a small $\mathrm{IrO}_{x}$ cluster consistent of merely a few atoms might form over time. Over a prolonged period of time, these small clusters can further aggregate to form larger $\mathrm{IrO}_{x}$ clusters that result in observed blue colloidal $\mathrm{IrO}_{x}$ solutions. The small $\mathrm{IrO}_{x}$ cluster might thus be responsible for the deposition and water oxidation activity on the GC electrode. This would also explain why a slightly aged $\left[\operatorname{Ir}(\mathrm{OH})_{6}\right]^{2-}$ solution has no lag time since it would contain a higher concentration of aggregated $\mathrm{IrO}_{x}$ clusters. It seems likely that a similar process takes place for the $\mathbf{1 - 5}$ catalyst precursors. In contrast to ligand-free $\left[\operatorname{Ir}(\mathrm{OH})_{6}\right]^{2-}$, the ligand is involved in the formation of these small, few-atom containing $\mathrm{IrO}_{x}$ clusters and might stabilize these to prevent agglomeration to large $\mathrm{IrO}_{x}$ clusters. The relatively small effect of the ligand on the binding energy of the $\mathrm{Ir} 4 \mathrm{f}_{7 / 2}$ species deposited on $\mathbf{G C l} \mathbf{1 - G C l} 4$ indicates that any ligand residues must be present in less than 1 ratio with respect to iridium atoms since the $1: 1$ or even $2: 1$ ratio of ligand to iridium in the parent complexes 1-4 directly results in larger shifts of the Ir $4 \mathrm{f}_{7 / 2}$ binding energies. The small ligand to iridium ratio also would also explain the small difference in water oxidation activity for GCl1-GCl4. In this context, it is interesting to note that the pyalc ligand appears to be most resistive to catalyst deactivation at higher potentials. We believe this is in line with reports by the Crabtree and Brudvig groups that claim that the pyalc ligand is retained in the catalytic species of their chemisorbed pyalc catalyst. ${ }^{14}$ This also illustrates that the choice of ligand has, though small, an influence on the outcome of the active species. Even more, with the right knowledge and choice of substituents, the size of the $\operatorname{IrO}_{x}$ agglomeration could be more precisely controlled, similar to the isolation of active sites in supports, allowing for enhanced water oxidation activity. ${ }^{13,73}$

\section{CONCLUSION}

We set out to benchmark the water oxidation performance of complexes 1-5 under the exact same electrochemical conditions. Previous studies with $\mathrm{NaIO}_{4}$ showed that the water oxidation activity of most complexes increased significantly when the $\mathrm{pH}$ was increased from 1 to 7 . By contrast, these complexes show minimal electrocatalytic activity, just barely above the background current of the glassy carbon electrode at $\mathrm{pH}$ 7. Our results show that the structureactivity relationships obtained in studies with sacrificial reagents do not translate under our electrochemical conditions where also the difference in activity between complexes seems to be rather marginal. All complexes do form deposits on the electrode surface, where they produce iridium sites that in terms of their electronic structure are barely influenced by the ligands that were present in the precatalyst. A possible explanation for this phenomenon is that small $\mathrm{IrO}_{x}$ clusters are formed. Ligands of the parent complexes or residues thereof might be incorporated and still influence the properties of these clusters. In terms of catalytic activity, the iridium deposits of the molecular complexes largely fall behind that of $\left[\operatorname{Ir}(\mathrm{OH})_{6}\right]^{2-}$, indicating that the remnants of the organic ligands have an inhibitory effect on the catalytic reaction. However, our catalyst screening study does show that the presence of organic ligands may in some cases result in slower catalyst deactivation and potentially retain more iridium sites available for the water oxidation reaction by preventing aggregation of these active sites.

\section{EXPERIMENTAL SECTION}

General. For all aqueous solutions, all experiments, and for cleaning of glassware, Milli-Q grade Ultrapure water $(>18.2$ $\mathrm{M} \Omega \mathrm{cm}$ resistivity) was used unless mentioned otherwise. Chemicals were bought from commercial suppliers and used as received without further purification. The $\mathrm{pH} 7$ (6.9) electrolyte was prepared with $\mathrm{NaH}_{2} \mathrm{PO}_{4}, \mathrm{Na}_{2} \mathrm{HPO}_{4}$ (both Merck Suprapur 99.99\%), and $\mathrm{NaClO}_{4} \cdot \mathrm{H}_{2} \mathrm{O}$ (Merck Emsure) in the right ratio to obtain an aqueous $0.1 \mathrm{M}$ phosphate buffer with an ionic strength of $0.5 \mathrm{M}$. This strengthened buffer was used for every experiment with a $\mathrm{pH} 7$ phosphate buffer. To obtain the $0.1 \mathrm{M} \mathrm{HClO}_{4}$ solution with an ionic strength of 0.5 $\mathrm{M}, \mathrm{HClO}_{4}$ (Merck Suprapur) and $\mathrm{NaClO}_{4}$ were used. $\mathrm{D}_{2} \mathrm{O}$ was obtained from Eurisotop and used as received. The $\mathrm{pH}$ was measured with a Hannah Instruments HI $4222 \mathrm{pH}$ meter that was calibrated with five IUPAC standard buffers. UV-vis measurements were performed on a Varian Cary $50 \mathrm{UV}-$ vis spectrometer. ${ }^{1} \mathrm{H}$ NMR measurements were performed with a Bruker DPX-300 $300 \mathrm{MHz}$ spectrometer.

The complexes ${ }^{\mathrm{H}} 1,{ }^{5-\mathrm{OH}} 1,2,3,4$, and 5 were all synthesized according to their published procedures. ${ }^{15,17,28,50,56} 3-\mathrm{OH} \mathbf{1}$, ${ }^{4-\mathrm{OH}_{1}} \mathbf{1}$, and ${ }^{6-\mathrm{OH}_{1}}$ were synthesized using 4 as an iridium precursor instead of $\left[\mathrm{Cp} * \mathrm{IrCl}_{2}\right]_{2}$. In particular, $100 \mathrm{mg}$ of 4 $(0.198 \mathrm{mmol})$ was added to a solution of $33.0 \mathrm{mg}$ of the ligand $(0.237 \mathrm{mmol})$ and $13.3 \mathrm{mg}$ of $\mathrm{KOH}(0.237 \mathrm{mmol})$ in $20 \mathrm{~mL}$ of $\mathrm{MeOH}$. The resulting solution was stirred at room temperature for $15 \mathrm{~h}$. The solvent was removed under a vacuum, and the residual solid was dissolved/suspended in DCM. The mixture was filtered through a membrane and the resulting solution reduced in volume, and the product was crystallized with diethyl ether. The yields were ca. 60-70\%. The corresponding ${ }^{1} \mathrm{H}$ NMR spectra (Figures S13-S15) in DMSO- $d_{6}$ match the spectra that were previously reported for the method using $\left[\mathrm{Cp}^{*} \mathrm{IrCl}_{2}\right]_{2}$ as a precursor. ${ }^{28}$

$\left[\operatorname{Ir}(\mathrm{OH})_{6}\right]^{2-}$ was prepared according to the procedure of Zhao et al. ${ }^{66}$ As described in their publication, control of $\mathrm{pH}$ is of importance. Specifically, we found that mixing the iridium 
precursor $\mathrm{K}_{2} \mathrm{IrCl}_{6}$ (Sigma) and $\mathrm{NaOH}$ (Fluka TraceSelect, $\geq$ 99.9995\%) in water should be in the proper atomic ratio; thus to convert $2 \mathrm{mM} \mathrm{K}_{2} \mathrm{IrCl}_{6}, 12 \mathrm{mM}$ of $\mathrm{NaOH}$ is required. Any excess of $\mathrm{NaOH}$ will result in a $\mathrm{pH}$ which is too high. Actually, in one attempt, a blue solution was obtained due to this excess. This deep blue $\mathrm{IrO}_{x}$ nanoparticle solution is the tested solution as described before.

General Electrochemistry. Electrochemical experiments were performed with a three-electrode setup in a custom-made, single-compartment glass cell. For EQCM and bulk electrolysis, special cells were used that are described separately. Autolab PGSTAT 204 and $128 \mathrm{~N}$ potentiostats were used in combination with NOVA 2.1 software. All glassware used for electrochemistry was cleaned by boiling in and copiously rinsing the glassware with water prior to each experiment. Periodically, the glassware was cleaned by immersing the glassware in a $1 \mathrm{~g} / \mathrm{L} \mathrm{KMnO}_{4}$ solution in 0.5 $\mathrm{M} \mathrm{H}_{2} \mathrm{SO}_{4}$ (Sigma, reagent grade) for at least a night. Afterward, the glassware was rinsed 10 times with water. Next, water and a few drops of $\mathrm{H}_{2} \mathrm{O}_{2}$ (Merck Emprove, 35\%) and $\mathrm{H}_{2} \mathrm{SO}_{4}$ were added to reoxidize any $\mathrm{MnO}_{2}$ residues. Subsequently, the glassware was rinsed and a 3-fold process of boiling the glassware in water and subsequent rinsing followed to finalize the cleaning.

All solutions were purged with argon (Linde, Ar 5.0) prior to each experiment for at least $30 \mathrm{~min}$, and the cell was kept under a flow of argon during the experiment.

All potentials are referenced to the reversible hydrogen electrode by utilizing a platinum mesh in a $\mathrm{H}_{2}$ (Linde, $\mathrm{H}_{2}$ 5.0) saturated electrolyte that is operated at the same $\mathrm{pH}$ as the working electrode. The cell and reference electrode are connected via a Luggin capillary. The counter electrode was a large surface area gold wire that is flame annealed prior to use. The working electrode was generally a glassy carbon electrode (Alfa Aesar type 1, $0.07 \mathrm{~cm}^{2}$ ) used in a hanging meniscus configuration or a PEEK encapsulated one (Metrohm, $0.07 \mathrm{~cm}^{2}$ ) that was specifically used for the CA studies, resulting in the plots and spectra in Figures 3 and 4. Regular polish was applied by mechanically polishing the electrode with 1.0, 0.3, and $0.05 \mu \mathrm{m}$ alumina slurry (Buehler) for $2 \mathrm{~min}$ followed by rinsing and sonicating the electrode in water for $15 \mathrm{~min}$. It has to be noted that the corrosive conditions under which the electrode was preanodized and used at high potentials for some of the experiments has a major destructive impact on the electrode itself. The surface is roughened extensively, which is reflected in a large increase in the capacitive current of the double layer. ${ }^{62}$ Only extensive polishing with sandpaper to remove a substantial amount of material from the surface and subsequent smoothing of the surface with alumina slurry was found to restore the electrode to an acceptable state. For this purpose, regular polishing was preceded by mechanical polishing with 600 and 2500 grit sandpaper, respectively.

OLEMS. The gaseous products that are detected with OLEMS are collected using a small tip that is in very close proximity to the working electrode. ${ }^{60}$ The working electrode is a large surface area $\left(0.14 \mathrm{~cm}^{2}\right)$ gold working electrode to maximize the current response. The tip was a porous Teflon cylinder $(0.5 \mathrm{~mm}$ diameter $)$ with an average pore size of $10-$ $14 \mu \mathrm{m}$ in a KeI-F holder. The mass spectrometer and the tip are interconnected via a PEEK capillary. The tip was cleaned in a solution of $\mathrm{K}_{2} \mathrm{Cr}_{2} \mathrm{O}_{7}(0.2 \mathrm{M})$ in $\mathrm{H}_{2} \mathrm{SO}_{4}(2 \mathrm{M})$ and rinsed with water before use. The measurements were performed with an IviumStat potentiostat operated by Ivium software.

Bulk Electrolysis. Bulk electrolysis was performed in a custom-made, two-compartment glass cell that could be separated with a Nafion membrane (Alfa Aesar, Nafion N117 membrane, $0.180 \mathrm{~mm}$ thick, $\geq 0.90$ mequiv/g exchange capacity) to allow for separation of the work and counter electrodes. The Nafion membrane is cleaned and activated by a 5-fold boiling and rinsing procedure in water, $5 \% \mathrm{H}_{2} \mathrm{O}_{2}$, water, 1.0 $\mathrm{M} \mathrm{H}_{2} \mathrm{SO}_{4}$, and water, respectively. This allows for optimal exchange capacitiy. ${ }^{74}$ However, as the final experiment was performed in $\mathrm{D}_{2} \mathrm{O}$, the Nafion membrane was dried in a $70{ }^{\circ} \mathrm{C}$ oven for $1 \mathrm{~h}$ to avoid contamination by $\mathrm{H}_{2} \mathrm{O}$. The reference electrode was a HydroFlex (Gaskatel) electrode used in a RHE configuration and connected via a Luggin capillary to the compartment with the work electrode. The work electrode was a custom-cut large surface area GC electrode $\left(0.79 \mathrm{~cm}^{2}\right)$ used in a hanging meniscus configuration which was preanodized in a $\mathrm{pH} 7$ phosphate electrolyte at $2.1 \mathrm{~V}$ for $25 \mathrm{~min}$. Afterward, the electrode was rinsed thoroughly with water and dried under a stream of $\mathrm{N}_{2}$. For the bulk electrolysis itself with $1 \mathrm{mM}$ ${ }^{4-\mathrm{OH}} 1$ present, a $\mathrm{D}_{2} \mathrm{O}$ based solution was used with $0.1 \mathrm{M}$ phosphate buffer and $0.5 \mathrm{M}$ ionic strength. This solution was used in the working electrode compartment. For the Luggin capillary and the counterelectrode compartments, a catalystfree $\mathrm{D}_{2} \mathrm{O}$ solution was used. The solution in the compartment for the working electrode was continuously stirred with a Teflon stirring bar that was cleaned according to the periodic glass cleaning procedure. A potential of $1.9 \mathrm{~V}$ was held for $1 \mathrm{~h}$ after which the catalyst solution was removed for further testing by NMR, DLS, and UV-vis. For UV-vis, the background was corrected for a catalyst-free solution, and the dilution was achieved by adding the appropriate amount of $\mathrm{D}_{2} \mathrm{O}$ to both the background and desired solution.

EQCM. EQCM experiments were performed with Autolab gold EQCM electrodes $\left(0.35 \mathrm{~cm}^{2}\right)$ in an Autolab $3 \mathrm{~mL}$ Teflon EQCM cell that consists of a $200 \mathrm{~nm}$ gold layer deposited on a quartz crystal. A modified RHE reference electrode was used, which prevents interference of continuous hydrogen bubbling to the sensitive microbalance signal. ${ }^{56}$

XPS. X-ray photoelectron spectroscopy (XPS) was performed on a Thermo Scientific K-Alpha spectrometer equipped with a monochromatic small-spot X-ray source and a double focusing hemispherical analyzer with a 128-channel delay line detector. Spectra were obtained by using an aluminum anode $(\mathrm{Al} \mathrm{K} \alpha=1486.6 \mathrm{eV})$ operated at $72 \mathrm{~W}$ and a spot size of $400 \mu \mathrm{m}$. Survey scans were measured at a constant pass energy of $200 \mathrm{eV}$, and high-resolution scans of the separate regions were measured at $50 \mathrm{eV}$ pass energy. The background pressure of the ultrahigh vacuum (UHV) chamber was $2 \times 10^{-8} \mathrm{mbar}$. Sample charging was compensated using an electron flood gun, and binding energy (BE) calibration was done by setting the $\mathrm{C} 1 \mathrm{~s}$ peak of $\mathrm{sp}^{3}(\mathrm{CH}, \mathrm{CC})$ carbon to $\mathrm{BE}$ $(\mathrm{C} 1 \mathrm{~s})=284.8 \mathrm{eV}$. For proper fitting of the data of $\mathbf{1}$ and 2, two different iridium species had to be fitted. For ${ }^{3-\mathrm{OH}} \mathbf{1}$, species at binding energies of $62.3(1) \mathrm{eV}$ and $60.8(1) \mathrm{eV}$ in a respective ratio of 17:1 were fitted. For ${ }^{4-\mathrm{OH}} \mathbf{1}$, a ratio of $21: 1$ between a fitted species at $62.1(1) \mathrm{eV}$ and $60.7(1) \mathrm{eV}$ was fitted. Last, 61.7 and $60.4 \mathrm{eV}$ (with a ratio of $11: 1$, respectively) were the fitted species for 2 . The numbers in parentheses are standard errors. Electrode samples for XPS analysis were prepared by performing amperometry at the desired potential $(1.95$ or $2.05 \mathrm{~V})$ with a GC electrode $\left(0.07 \mathrm{~cm}^{2}\right)$ in a hanging 
meniscus configuration for $30 \mathrm{~min}$. The electrode was preanodized for $25 \mathrm{~min}$ at $2.1 \mathrm{~V}$ in a catalyst-free $\mathrm{pH} 7$ phosphate buffer electrolyte. After subsequent rinsing with water, the electrode was held in electrolyte that contained 1 $\mathrm{mM}$ of the complex of interest. After amperometry, the electrode was rinsed with water and air-dried before being subjected to XPS analysis.

\section{ASSOCIATED CONTENT}

\section{SI Supporting Information}

The Supporting Information is available free of charge at https://pubs.acs.org/doi/10.1021/acscatal.0c00531.

CVs of $1,{ }^{1} \mathrm{H}$ NMR and UV-vis spectra of the electrolyte after bulk electrolysis with ${ }^{4-\mathrm{OH}} \mathbf{1}$, chronoamperometry data of $\mathbf{1 - 5}$ without preanodized GC electrodes, $\mathrm{N}$ 1s and $\mathrm{O}$ 1s XPS spectra, chronoamperometry and CVs of $\left[\operatorname{Ir}(\mathrm{OH})_{6}\right]^{2-}$ and colloidal $\mathrm{IrO}_{x}$ solutions, and ${ }^{1} \mathrm{H}$ NMR spectra of ${ }^{3-, 4-5-5-6-\mathrm{OH}} \mathbf{1}$ (PDF)

\section{AUTHOR INFORMATION}

\section{Corresponding Authors}

Dennis G. H. Hetterscheid - Leiden Institute of Chemistry, Leiden University, 2300 RA Leiden, The Netherlands; ○ orcid.org/0000-0001-5640-4416;

Email: d.g.h.hetterscheid@chem.leidenuniv.nl

Alceo Macchioni - Department of Chemistry, Biology and Biotechnology and CIRCC, University of Perugia, 06123 Perugia, Italy; 이이이.org/0000-0001-7866-8332; Email: alceo.macchioni@unipg.it

\section{Authors}

Bas van Dijk - Leiden Institute of Chemistry, Leiden University, 2300 RA Leiden, The Netherlands

Gabriel Menendez Rodriguez - Department of Chemistry, Biology and Biotechnology and CIRCC, University of Perugia, 06123 Perugia, Italy

Longfei Wu - Laboratory for Inorganic Materials and Catalysis, Department of Chemical Engineering and Chemistry, Eindhoven University of Technology, 5600 MB Eindhoven, The Netherlands

Jan P. Hofmann - Laboratory for Inorganic Materials and Catalysis, Department of Chemical Engineering and Chemistry, Eindhoven University of Technology, $5600 \mathrm{MB}$ Eindhoven, The

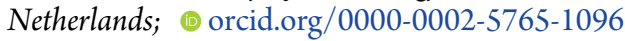

Complete contact information is available at:

https://pubs.acs.org/10.1021/acscatal.0c00531

\section{Notes}

The authors declare no competing financial interest.

\section{ACKNOWLEDGMENTS}

This work has been financially supported by the European Research Council (ERC starting grant 637556 Cu4Energy to D.G.H.H.), PRIN 2015 (20154X9ATP_004), University of Perugia and MIUR (AMIS, "Dipartimenti di Eccellenza 20182022" program). L.W. and J.P.H. acknowledge funding from The Netherlands Organization for Scientific Research (NWO) and cofinancing by Shell Global Solutions International B.V. for the project $13 \mathrm{CO} 2-6$.

\section{REFERENCES}

(1) Blakemore, J. D.; Crabtree, R. H.; Brudvig, G. W. Molecular Catalysts for Water Oxidation. Chem. Rev. 2015, 115, 12974-13005.

(2) Fukuzumi, S.; Hong, D. Homogeneous versus Heterogeneous Catalysts in Water Oxidation. Eur. J. Inorg. Chem. 2014, 2014, 645659.

(3) Hetterscheid, D. G. H.; Reek, J. N. H. Mononuclear Water Oxidation Catalysts. Angew. Chem., Int. Ed. 2012, 51, 9740-9747.

(4) Kärkäs, M. D.; Verho, O.; Johnston, E. V.; Åkermark, B. Artificial Photosynthesis: Molecular Systems for Catalytic Water Oxidation. Chem. Rev. 2014, 114, 11863-12001.

(5) Liu, X.; Wang, F. Transition metal complexes that catalyze oxygen formation from water: 1979-2010. Coord. Chem. Rev. 2012, $256,1115-1136$.

(6) Macchioni, A. The Middle-Earth between Homogeneous and Heterogeneous Catalysis in Water Oxidation with Iridium. Eur. J. Inorg. Chem. 2019, 2019, 7-17.

(7) Seidler-Egdal, R. K.; Nielsen, A.; Bond, A. D.; Bjerrum, M. J.; McKenzie, C. J. High turnover catalysis of water oxidation by $\mathrm{Mn}$ (II) complexes of monoanionic pentadentate ligands. Dalton Trans. 2011, 40, 3849-3858.

(8) Thomsen, J. M.; Huang, D. L.; Crabtree, R. H.; Brudvig, G. W. Iridium-based complexes for water oxidation. Dalton Trans. 2015, 44, $12452-12472$.

(9) Wu, X.; Li, F.; Zhang, B.; Sun, L. Molecular complexes in water oxidation: Pre-catalysts or real catalysts. J. Photochem. Photobiol., C 2015, 25, 71-89.

(10) Yagi, M.; Syouji, A.; Yamada, S.; Komi, M.; Yamazaki, H.; Tajima, S. Molecular catalysts for water oxidation toward artificial photosynthesis. Photochem. Photobiol. Sci. 2009, 8, 139-147.

(11) Zhang, B.; Sun, L. Artificial photosynthesis: opportunities and challenges of molecular catalysts. Chem. Soc. Rev. 2019, 48, 22162264.

(12) Duan, L.; Fischer, A.; Xu, Y.; Sun, L. Isolated Seven-Coordinate $\mathrm{Ru}(\mathrm{IV})$ Dimer Complex with $[\mathrm{HOHOH}]^{-}$Bridging Ligand as an Intermediate for Catalytic Water Oxidation. J. Am. Chem. Soc. 2009, 131, 10397-10399.

(13) Fagiolari, L.; Zaccaria, F.; Costantino, F.; Vivani, R.; Mavrokefalos, C.; Patzke, G.; Macchioni, A. Ir- and Ru-doped layered double hydroxides as affordable heterogeneous catalysts for electrochemical water oxidation. Dalton Trans. 2020, 49, 2468.

(14) Sheehan, S. W.; Thomsen, J. M.; Hintermair, U.; Crabtree, R. H.; Brudvig, G. W.; Schmuttenmaer, C. A. A molecular catalyst for water oxidation that binds to metal oxide surfaces. Nat. Commun. 2015, 6, 6469.

(15) McDaniel, N. D.; Coughlin, F. J.; Tinker, L. L.; Bernhard, S. Cyclometalated Iridium(III) Aquo Complexes: Efficient and Tunable Catalysts for the Homogeneous Oxidation of Water. J. Am. Chem. Soc. 2008, 130, 210-217.

(16) Blakemore, J. D.; Schley, N. D.; Balcells, D.; Hull, J. F.; Olack, G. W.; Incarvito, C. D.; Eisenstein, O.; Brudvig, G. W.; Crabtree, R. H. Half-Sandwich Iridium Complexes for Homogeneous WaterOxidation Catalysis. J. Am. Chem. Soc. 2010, 132, 16017-16029.

(17) Savini, A.; Bellachioma, G.; Ciancaleoni, G.; Zuccaccia, C.; Zuccaccia, D.; Macchioni, A. Iridium(III) molecular catalysts for water oxidation: the simpler the faster. Chem. Commun. 2010, 46, 9218-9219.

(18) Bucci, A.; Savini, A.; Rocchigiani, L.; Zuccaccia, C.; Rizzato, S.; Albinati, A.; Llobet, A.; Macchioni, A. Organometallic Iridium Catalysts Based on Pyridinecarboxylate Ligands for the Oxidative Splitting of Water. Organometallics 2012, 31, 8071-8074.

(19) DePasquale, J.; Nieto, I.; Reuther, L. E.; Herbst-Gervasoni, C. J.; Paul, J. J.; Mochalin, V.; Zeller, M.; Thomas, C. M.; Addison, A. W.; Papish, E. T. Iridium Dihydroxybipyridine Complexes Show That Ligand Deprotonation Dramatically Speeds Rates of Catalytic Water Oxidation. Inorg. Chem. 2013, 52, 9175-9183.

(20) Savini, A.; Bucci, A.; Bellachioma, G.; Giancola, S.; Palomba, F.; Rocchigiani, L.; Rossi, A.; Suriani, M.; Zuccaccia, C.; Macchioni, A. New iridium(III) organometallic complexes bearing strong electron 
donating bidentate ligands as catalysts for water oxidation. J. Organomet. Chem. 2014, 771, 24-32.

(21) Li, M.; Takada, K.; Goldsmith, J. I.; Bernhard, S. Iridium(III) Bis-Pyridine-2-Sulfonamide Complexes as Efficient and Durable Catalysts for Homogeneous Water Oxidation. Inorg. Chem. 2016, $55,518-526$.

(22) Bucci, A.; Dunn, S.; Bellachioma, G.; Menendez Rodriguez, G.; Zuccaccia, C.; Nervi, C.; Macchioni, A. A Single Organoiridium Complex Generating Highly Active Catalysts for both Water Oxidation and $\mathrm{NAD}^{+} / \mathrm{NADH}$ Transformations. ACS Catal. 2017, 7, 7788-7796.

(23) Li, M.; Bernhard, S. Synthetically tunable iridium(III) bispyridine-2-sulfonamide complexes as efficient and durable water oxidation catalysts. Catal. Today 2017, 290, 19-27.

(24) Mahanti, B.; González Miera, G.; Martínez-Castro, E.; Bedin, M.; Martín-Matute, B.; Ott, S.; Thapper, A. Homogeneous Water Oxidation by Half-Sandwich Iridium(III) N-Heterocyclic Carbene Complexes with Pendant Hydroxy and Amino Groups. ChemSusChem 2017, 10, 4616-4623.

(25) Navarro, M.; Li, M.; Bernhard, S.; Albrecht, M. A mesoionic nitrogen-donor ligand: structure, iridium coordination, and catalytic effects. Dalton Trans. 2018, 47, 659-662.

(26) Navarro, M.; Smith, C. A.; Li, M.; Bernhard, S.; Albrecht, M. Optimization of Synthetically Versatile Pyridylidene Amide Ligands for Efficient Iridium-Catalyzed Water Oxidation. Chem. - Eur. J. 2018, 24, 6386-6398.

(27) Menendez Rodriguez, G.; Gatto, G.; Zuccaccia, C.; Macchioni, A. Benchmarking Water Oxidation Catalysts Based on Iridium Complexes: Clues and Doubts on the Nature of Active Species. ChemSusChem 2017, 10, 4503-4509.

(28) Menendez Rodriguez, G.; Bucci, A.; Hutchinson, R.; Bellachioma, G.; Zuccaccia, C.; Giovagnoli, S.; Idriss, H.; Macchioni, A. Extremely Active, Tunable, and $\mathrm{pH}$-Responsive Iridium Water Oxidation Catalysts. ACS Energy Lett. 2017, 2, 105-110.

(29) Grotjahn, D. B.; Brown, D. B.; Martin, J. K.; Marelius, D. C.; Abadjian, M.-C.; Tran, H. N.; Kalyuzhny, G.; Vecchio, K. S.; Specht, Z. G.; Cortes-Llamas, S. A.; Miranda-Soto, V.; van Niekerk, C.; Moore, C. E.; Rheingold, A. L. Evolution of Iridium-Based Molecular Catalysts during Water Oxidation with Ceric Ammonium Nitrate. J. Am. Chem. Soc. 2011, 133, 19024-19027.

(30) Savini, A.; Belanzoni, P.; Bellachioma, G.; Zuccaccia, C.; Zuccaccia, D.; Macchioni, A. Activity and degradation pathways of pentamethyl-cyclopentadienyl-iridium catalysts for water oxidation. Green Chem. 2011, 13, 3360-3374.

(31) Bucci, A.; Menendez Rodriguez, G.; Bellachioma, G.; Zuccaccia, C.; Poater, A.; Cavallo, L.; Macchioni, A. An Alternative Reaction Pathway for Iridium-Catalyzed Water Oxidation Driven by Cerium Ammonium Nitrate (CAN). ACS Catal. 2016, 6, 4559-4563.

(32) Corbucci, I.; Zaccaria, F.; Heath, R.; Gatto, G.; Zuccaccia, C.; Albrecht, M.; Macchioni, A. Iridium Water Oxidation Catalysts Based on Pyridine-Carbene Alkyl-Substituted Ligands. Chem CatChem 2019, 11, 5353-5361.

(33) Blakemore, J. D.; Schley, N. D.; Olack, G. W.; Incarvito, C. D.; Brudvig, G. W.; Crabtree, R. H. Anodic deposition of a robust iridium-based water-oxidation catalyst from organometallic precursors. Chem. Sci. 2011, 2, 94-98.

(34) Zuccaccia, C.; Bellachioma, G.; Bolaño, S.; Rocchigiani, L.; Savini, A.; Macchioni, A. An NMR Study of the Oxidative Degradation of Cp*Ir Catalysts for Water Oxidation: Evidence for a Preliminary Attack on the Quaternary Carbon Atom of the -CCH3Moiety. Eur. J. Inorg. Chem. 2012, 2012, 1462-1468.

(35) Hong, D.; Murakami, M.; Yamada, Y.; Fukuzumi, S. Efficient water oxidation by cerium ammonium nitrate with $\left[\operatorname{Ir}^{\mathrm{III}}\left(\mathrm{Cp}^{*}\right)\left(4,4^{\prime}\right.\right.$ bishydroxy-2,2'-bipyridine $)(\mathrm{H} 2 \mathrm{O})]^{2+}$ as a precatalyst. Energy Environ. Sci. 2012, 5, 5708-5716.

(36) Wang, C.; Wang, J.-L.; Lin, W. Elucidating Molecular Iridium Water Oxidation Catalysts Using Metal-Organic Frameworks: A Comprehensive Structural, Catalytic, Spectroscopic, and Kinetic Study. J. Am. Chem. Soc. 2012, 134, 19895-19908.
(37) Hintermair, U.; Sheehan, S. W.; Parent, A. R.; Ess, D. H.; Richens, D. T.; Vaccaro, P. H.; Brudvig, G. W.; Crabtree, R. H. Precursor Transformation during Molecular Oxidation Catalysis with Organometallic Iridium Complexes. J. Am. Chem. Soc. 2013, 135, 10837-10851.

(38) Blakemore, J. D.; Mara, M. W.; Kushner-Lenhoff, M. N.; Schley, N. D.; Konezny, S. J.; Rivalta, I.; Negre, C. F. A.; Snoeberger, R. C.; Kokhan, O.; Huang, J.; Stickrath, A.; Tran, L. A.; Parr, M. L.; Chen, L. X.; Tiede, D. M.; Batista, V. S.; Crabtree, R. H.; Brudvig, G. W. Characterization of an Amorphous Iridium Water-Oxidation Catalyst Electrodeposited from Organometallic Precursors. Inorg. Chem. 2013, 52, 1860-1871.

(39) Codolà, Z.; M. S. Cardoso, J.; Royo, B.; Costas, M.; LloretFillol, J. Highly Effective Water Oxidation Catalysis with Iridium Complexes through the Use of $\mathrm{NaIO}_{4}$. Chem. - Eur. J. 2013, 19, $7203-7213$.

(40) Graeupner, J.; Hintermair, U.; Huang, D. L.; Thomsen, J. M.; Takase, M.; Campos, J.; Hashmi, S. M.; Elimelech, M.; Brudvig, G. W.; Crabtree, R. H. Probing the Viability of Oxo-Coupling Pathways in Iridium-Catalyzed Oxygen Evolution. Organometallics 2013, 32, $5384-5390$.

(41) Zuccaccia, C.; Bellachioma, G.; Bortolini, O.; Bucci, A.; Savini, A.; Macchioni, A. Transformation of a $\mathrm{Cp}^{*}$-Iridium(III) Precatalyst for Water Oxidation when Exposed to Oxidative Stress. Chem. - Eur. J. 2014, 20, 3446-3456.

(42) Savini, A.; Bucci, A.; Bellachioma, G.; Rocchigiani, L.; Zuccaccia, C.; Llobet, A.; Macchioni, A. Mechanistic Aspects of Water Oxidation Catalyzed by Organometallic Iridium Complexes. Eur. J. Inorg. Chem. 2014, 2014, 690-697.

(43) Ingram, A. J.; Wolk, A. B.; Flender, C.; Zhang, J.; Johnson, C. J.; Hintermair, U.; Crabtree, R. H.; Johnson, M. A.; Zare, R. N. Modes of Activation of Organometallic Iridium Complexes for Catalytic Water and C-H Oxidation. Inorg. Chem. 2014, 53, 423-433.

(44) Thomsen, J. M.; Sheehan, S. W.; Hashmi, S. M.; Campos, J.; Hintermair, U.; Crabtree, R. H.; Brudvig, G. W. Electrochemical Activation of $\mathrm{Cp}^{*}$ Iridium Complexes for Electrode-Driven WaterOxidation Catalysis. J. Am. Chem. Soc. 2014, 136, 13826-13834.

(45) Zhang, T.; deKrafft, K. E.; Wang, J.-L.; Wang, C.; Lin, W. The Effects of Electron-Donating Substituents on $[\mathrm{Ir}(\mathrm{bpy}) \mathrm{Cp} * \mathrm{Cl}]^{+}$: Water Oxidation versus Ligand Oxidative Modifications. Eur. J. Inorg. Chem. 2014, 2014, 698-707.

(46) Lewandowska-Andralojc, A.; Polyansky, D. E.; Wang, C.-H.; Wang, W.-H.; Himeda, Y.; Fujita, E. Efficient water oxidation with organometallic iridium complexes as precatalysts. Phys. Chem. Chem. Phys. 2014, 16, 11976-11987.

(47) Wan, X.; Wang, L.; Dong, C.-L.; Menendez Rodriguez, G.; Huang, Y.-C.; Macchioni, A.; Shen, S. Activating Kläui-Type Organometallic Precursors at Metal Oxide Surfaces for Enhanced Solar Water Oxidation. ACS Energy Lett. 2018, 3, 1613-1619.

(48) Dzik, W. I.; Calvo, S. E.; Reek, J. N. H.; Lutz, M.; Ciriano, M. A.; Tejel, C.; Hetterscheid, D. G. H.; de Bruin, B. Binuclear $[(\operatorname{cod})(\mathrm{Cl}) \operatorname{Ir}(\mathrm{bpi}) \operatorname{Ir}(\operatorname{cod})]^{+}$for Catalytic Water Oxidation. Organometallics 2011, 30, 372-374.

(49) Brewster, T. P.; Blakemore, J. D.; Schley, N. D.; Incarvito, C. D.; Hazari, N.; Brudvig, G. W.; Crabtree, R. H. An Iridium(IV) Species, $[\mathrm{Cp} * \operatorname{Ir}(\mathrm{NHC}) \mathrm{Cl}]^{+}$, Related to a Water-Oxidation Catalyst. Organometallics 2011, 30, 965-973.

(50) Schley, N. D.; Blakemore, J. D.; Subbaiyan, N. K.; Incarvito, C. D.; D’Souza, F.; Crabtree, R. H.; Brudvig, G. W. Distinguishing Homogeneous from Heterogeneous Catalysis in Electrode-Driven Water Oxidation with Molecular Iridium Complexes. J. Am. Chem. Soc. 2011, 133, 10473-10481.

(51) Blakemore, J. D.; Schley, N. D.; Kushner-Lenhoff, M. N.; Winter, A. M.; D’Souza, F.; Crabtree, R. H.; Brudvig, G. W. Comparison of Amorphous Iridium Water-Oxidation Electrocatalysts Prepared from Soluble Precursors. Inorg. Chem. 2012, 51, 7749-7763.

(52) Hintermair, U.; Hashmi, S. M.; Elimelech, M.; Crabtree, R. H. Particle Formation during Oxidation Catalysis with $\mathrm{Cp}^{*}$ Iridium Complexes. J. Am. Chem. Soc. 2012, 134, 9785-9795. 
(53) Junge, H.; Marquet, N.; Kammer, A.; Denurra, S.; Bauer, M.; Wohlrab, S.; Gärtner, F.; Pohl, M.-M.; Spannenberg, A.; Gladiali, S.; Beller, M. Water Oxidation with Molecularly Defined Iridium Complexes: Insights into Homogeneous versus Heterogeneous Catalysis. Chem. - Eur. J. 2012, 18, 12749-12758.

(54) Diaz-Morales, O.; Hersbach, T. J. P.; Hetterscheid, D. G. H.; Reek, J. N. H.; Koper, M. T. M. Electrochemical and Spectroelectrochemical Characterization of an Iridium-Based Molecular Catalyst for Water Splitting: Turnover Frequencies, Stability, and Electrolyte Effects. J. Am. Chem. Soc. 2014, 136, 10432-10439.

(55) Hetterscheid, D. G. H.; van der Ham, C. J. M.; Diaz-Morales, O.; Verhoeven, M. W. G. M.; Longo, A.; Banerjee, D.; Niemantsverdriet, J. W.; Reek, J. N. H.; Feiters, M. C. Early stages of catalyst aging in the iridium mediated water oxidation reaction. Phys. Chem. Chem. Phys. 2016, 18, 10931-10940.

(56) Abril, P.; del Rio, M. P.; Tejel, C.; Verhoeven, T. W. G. M.; Niemantsverdriet, J. W. H.; Van der Ham, C. J. M.; Kottrup, K. G.; Hetterscheid, D. G. H. Detangling Catalyst Modification Reactions from the Oxygen Evolution Reaction by Online Mass Spectrometry. ACS Catal. 2016, 6, 7872-7875.

(57) Corbucci, I.; Ellingwood, K.; Fagiolari, L.; Zuccaccia, C.; Elisei, F.; Gentili, P. L.; Macchioni, A. Photocatalytic water oxidation mediated by iridium complexes. Catal. Today 2017, 290, 10-18.

(58) van Dijk, B.; Hofmann, J. P.; Hetterscheid, D. G. H. Pinpointing the active species of the $\mathrm{Cu}(\mathrm{DAT})$ catalyzed oxygen reduction reaction. Phys. Chem. Chem. Phys. 2018, 20, 19625-19634. (59) Joya, K. S.; Subbaiyan, N. K.; D’Souza, F.; de Groot, H. J. M. Surface-Immobilized Single-Site Iridium Complexes for Electrocatalytic Water Splitting. Angew. Chem., Int. Ed. 2012, 51, 9601-9605.

(60) Wonders, A. H.; Housmans, T. H. M.; Rosca, V.; Koper, M. T. $\mathrm{M}$. On-line mass spectrometry system for measurements at singlecrystal electrodes in hanging meniscus configuration. J. Appl. Electrochem. 2006, 36, 1215-1221.

(61) Diaz-Morales, O.; Calle-Vallejo, F.; de Munck, C.; Koper, M. T. M. Electrochemical water splitting by gold: evidence for an oxide decomposition mechanism. Chem. Sci. 2013, 4, 2334.

(62) Yi, Y.; Weinberg, G.; Prenzel, M.; Greiner, M.; Heumann, S.; Becker, S.; Schlögl, R. Electrochemical corrosion of a glassy carbon electrode. Catal. Today 2017, 295, 32-40.

(63) van der Ham, C. J. M.; Işık, F.; Verhoeven, T. W. G. M.; Niemantsverdriet, J. W.; Hetterscheid, D. G. H. Activation pathways taking place at molecular copper precatalysts for the oxygen evolution reaction. Catal. Today 2017, 290, 33-38.

(64) Hetterscheid, D. G. H. In operando studies on the electrochemical oxidation of water mediated by molecular catalysts. Chem. Commun. 2017, 53, 10622-10631.

(65) Zhao, Y.; Hernandez-Pagan, E. A.; Vargas-Barbosa, N. M.; Dysart, J. L.; Mallouk, T. E. A High Yield Synthesis of Ligand-Free Iridium Oxide Nanoparticles with High Electrocatalytic Activity. J. Phys. Chem. Lett. 2011, 2, 402-406.

(66) Zhao, Y.; Vargas-Barbosa, N. M.; Hernandez-Pagan, E. A.; Mallouk, T. E. Anodic Deposition of Colloidal Iridium Oxide Thin Films from Hexahydroxyiridate(IV) Solutions. Small 2011, 7, 20872093.

(67) Bard, A. J.; Faulkner, L. R. Electrochemical Methods: Fundamentals and Applications; Wiley: New York, 2000.

(68) Diaz-Morales, O.; Raaijman, S.; Kortlever, R.; Kooyman, P. J.; Wezendonk, T.; Gascon, J.; Fu, W. T.; Koper, M. T. M. Iridium-based double perovskites for efficient water oxidation in acid media. Nat. Commun. 2016, 7, 12363.

(69) NIST X-ray Photoelectron Spectroscopy Database, version 4.1; National Institute of Standards and Technology: Gaithersburg, 2012. http://srdata.nist.gov/xps/.

(70) Rubel, M.; Haasch, R.; Mrozek, P.; Wieckowski, A.; De Pauli, C.; Trasatti, S. Characterization of $\mathrm{IrO}_{2}-\mathrm{SnO}_{2}$ thin layers by electron and ion spectroscopies. Vacuum 1994, 45, 423-427.

(71) Kötz, R.; Neff, H.; Stucki, S. Anodic Iridium Oxide Films: XPSStudies of Oxidation State Changes and. J. Electrochem. Soc. 1984, 131, 72-77.
(72) Huang, D. L.; Beltrán-Suito, R.; Thomsen, J. M.; Hashmi, S. M.; Materna, K. L.; Sheehan, S. W.; Mercado, B. Q.; Brudvig, G. W.; Crabtree, R. H. New Ir Bis-Carbonyl Precursor for Water Oxidation Catalysis. Inorg. Chem. 2016, 55, 2427-2435.

(73) Corbucci, I.; Petronilho, A.; Müller-Bunz, H.; Rocchigiani, L.; Albrecht, M.; Macchioni, A. Substantial Improvement of PyridineCarbene Iridium Water Oxidation Catalysts by a Simple Methyl-toOctyl Substitution. ACS Catal. 2015, 5, 2714-2718.

(74) Jiang, B.; Yu, L.; Wu, L.; Mu, D.; Liu, L.; Xi, J.; Qiu, X. Insights into the Impact of the Nafion Membrane Pretreatment Process on Vanadium Flow Battery Performance. ACS Appl. Mater. Interfaces 2016, 8, 12228-12238. 